\title{
Sympathetic Outflows from Cervical Spinal Cord in the Dog
}

\author{
Gary Gene Wiesman \\ Loyola University Chicago
}

Follow this and additional works at: https://ecommons.luc.edu/luc_theses

Part of the Medicine and Health Sciences Commons

\section{Recommended Citation}

Wiesman, Gary Gene, "Sympathetic Outflows from Cervical Spinal Cord in the Dog" (1968). Master's Theses. 2255.

https://ecommons.luc.edu/luc_theses/2255

This Thesis is brought to you for free and open access by the Theses and Dissertations at Loyola eCommons. It has been accepted for inclusion in Master's Theses by an authorized administrator of Loyola eCommons. For more information, please contact ecommons@luc.edu. (c) $($ ) $(9)$

This work is licensed under a Creative Commons Attribution-Noncommercial-No Derivative Works 3.0 License. Copyright (C) 1968 Gary Gene Wiesman 


\section{SYMPATHRTIC OUTFLOHS FROM \\ CERVICAL SPIMAL CORD IN \\ THE DOG}

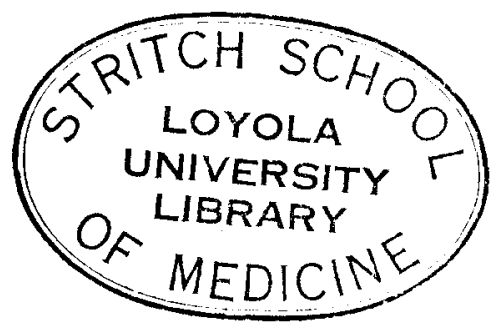

by

Gary Gene WLesman

A Thesis submitted to the raculty of the Graduate school of Loyola onlvarsity in Partial Fulf111ment of the Reguirement: for the Degree of

Manter of selence

Fobruary 


\section{BTOCRAPfY}

Gary Gene WLeunas was born on betober 7, 1942, In Granlta city. Illinole.

Ie wa graduated from the Grantea clty Sendor High Bchool In June, 1960. He attended washington Dniveralty, 8t. Loula, Miecur1, and was awarded the Bachelor of Arte degree in June, 1963.

In september, 1963, he bequn his graduate etudies in the Dapurtwent of Anatomy, Loyoln Univeralty, stritch sohool of Mediolne, Chleago, IIIfaole. He we the rectpient of a royola unlversity Graduete student reaching avistantohip in the Dapartwant of Anatomy, and his research wer apported by an vin Grant and Fe12ownip.

In September, 1964, he bagen atudien in Loyola oniveraity, stritch sehool of Modiclne, and w12 recolve his M.D. In June, 2968. 


\section{ACKHOWLSDGRHAWT}

I Wh to exprese my alnoer. appreclation to Dr. Davld 5. Jones, Professor of Anatomy, and to Dr. Walter C. Mnndall, Chatran, Department of Phyalology, for thelr guiding enpervialon and

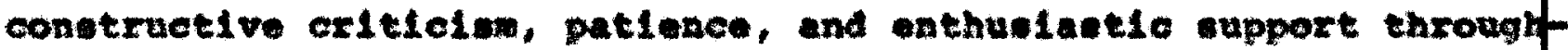
out this Inventigation.

My thenks are aleo due to Dr. Les110 $A$. Fmert, Abeletent Profeasor of Anatomy, for hie thoughtel cxitlelwas and auggestons on ceohnical problean.

I alwo would like to exprese ay aptroclation to Dr. Jose V. Kannanklud, Research Mawoolate In Matomy, for hls encouregomant and ganerost ty of time, without whowe oounel this undertaklng would have been conslderably more difleult.

Appreolation is also extended to Mra. Luola smelte, Seniox Techniclan, Departwent of Anatomy, for hex advice coneerning tisaue preparation, and to Mr. John Marer, "hitoul school photographer. for his expert advioe conoerning photomioregraphy.

The study was apportad in part by Matlonal Inet1tutes of bealth renearoh grant nxos682, and by grante adminictered by Dr. Malter C. Randall. 
ThLe or conarws

Page

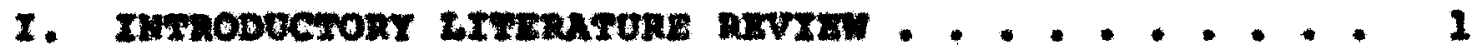

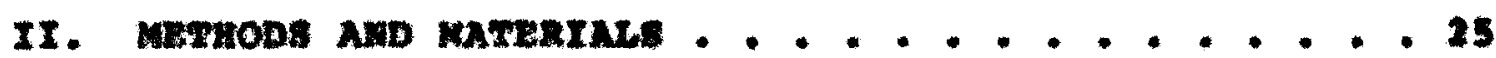

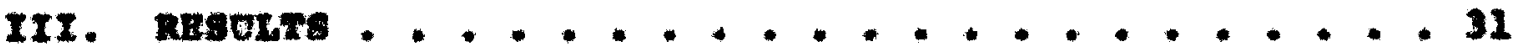

I. Caxdlovawoular respones to electrioal etimulation of vantral roote of cervieal cord

II. Hintological analyala of oerviond enterior zoots

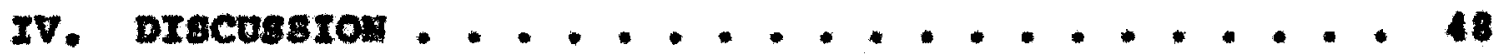

v. semanar and conczusron .................. 52

vx. Brmirocnapar ........................ 33 
LIET OF TAELEB AND RTCURTS

Table

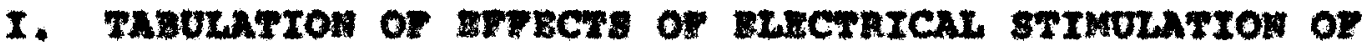

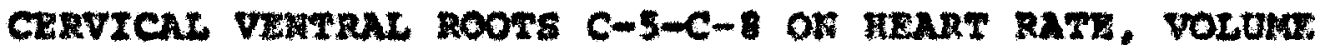

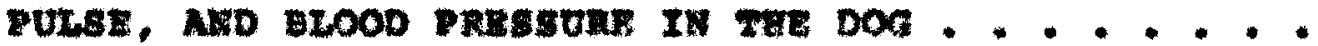

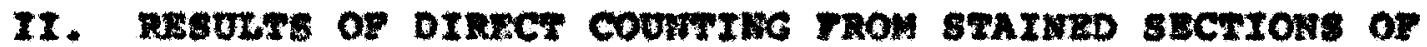

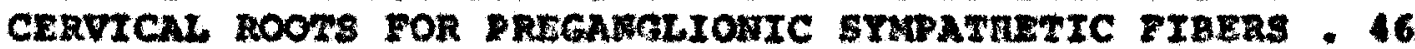

Igare

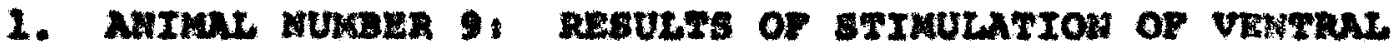

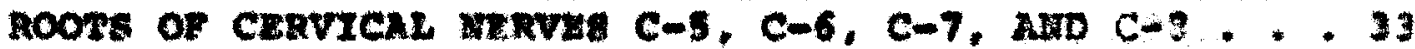

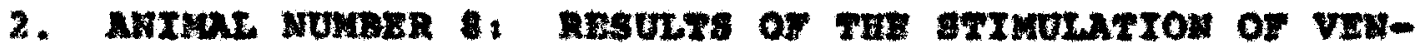

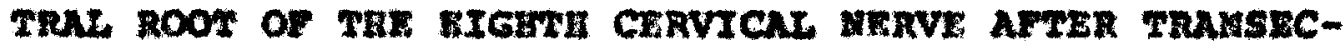

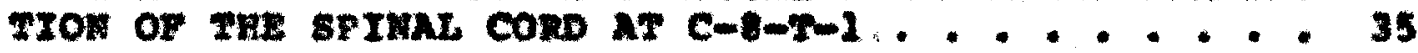

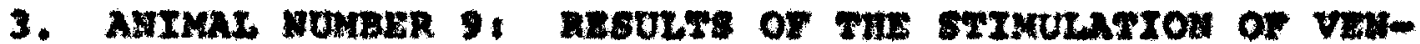

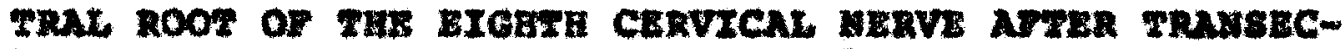

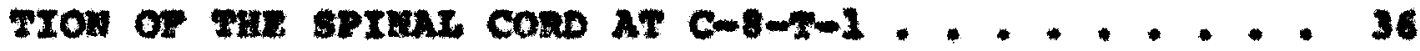

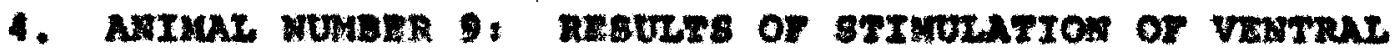

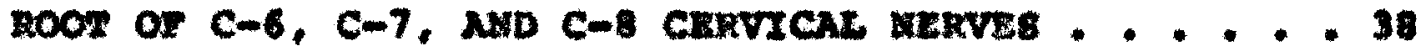

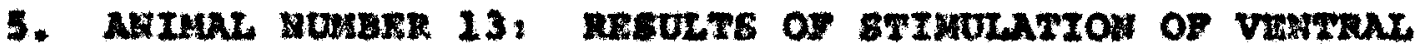

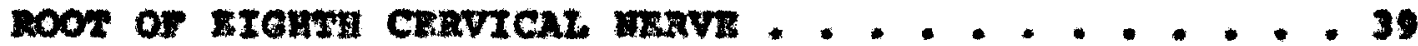

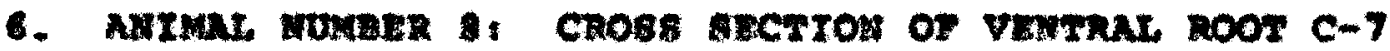

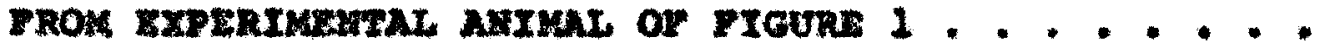

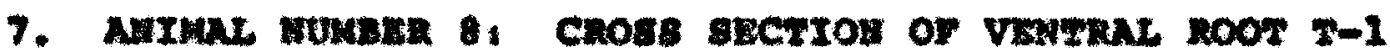

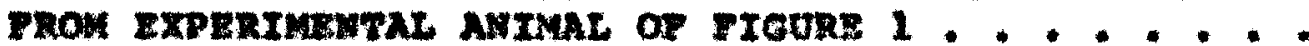




\section{IXFRODUCTORY EXTRRATURE REVIRW}

The earliest anatomical deacription of any part of the autonomle nervous aystem probably dates back to sajen's account of the nerve trunk $1 y$ ing along the necks of the ribs receiving Elbers from thoracic and lumbar portions of the spinal cord. $\lambda$ declstve acoount of the anatomital and physlological ralationships of the ANs was not polnted out untll Gaskell $(1886)^{25}$ gave an acoount of the white comanicating rand and their distribution. We pointed out that the afferent flbors in these rami arlse In the eplnal cord in cell colwns which are Interrupted by the development of the nexve: to the Ilmbe and that correoponding fibur: also oceur in certain of the cranlal nerves. There exiet alwo three outflows of medullated nerve flbers of anall callber, the bulbar, the thoraco-1 tubar and the accral. through wich the peripherally located efferent ganglion cell: are connected with the Cws. Gakell (1899) also treced fiber: In the ranl comaunleantes and roots of the opinal narves denonstrating the seqmantal nature of nerven to the pexiphery. 26 From the above obeervations Gakell coneluded that the autonomic outflow consists of a two neuron pathwey aystex, the white 
communlcating rand contalning the frot part of the pathway and the rami communicantes the accond part. In his later work, ankel1 $(1916)^{27}$ uned the texm "involuntary nexvous syetem" to deslgnute those effexent neurone located outilde the cus which apply flbera to involantary atruetures.

rangley and btakinson $(1890)^{4}$ atecovered in the notion of nicotine on the ganglia now uthod of investigating the relationihtp of nerve flber: to paxiphexal ganglion ocile. They domonatrated that nicotina injections wtoppod awenting and akin pallor produced by atianlation of raml coming from the cord, but the effect of etimulattom of peripheral ramiflotion of sympathetic chaln were not affected by nicotine, therefore abotantlating Gekell' concept of two nouron symen in the Ave. The remulta obtalned by the use of this method led Langley $(1921)^{16}$ to propose a naw terrs" "autonom10 nexvou: system", for the aysten of nervas in quastion. When the term "attonowio" was Introduced by Lungley, it was well known that the thoracolumbar outflow through the wypathetlc trunk sapplles ftbers to all parts of the body, while the exanlal and sacral outflows oupply fiber: only to certain part: of the body. Alwo, tunctional effect Induced by actiratIon of thoxacolumber autflow, In genaral, wer the opposite of those of the cranlal and ackal outelown. Iangley, theretore, regarded the thoracolumbar outflew as a system dintinct from the rest of the abtonomle nerves. Also, he regardad the thoracla 
outflow supplying the eyo an distinot frow the eranial part of the outflow, whah with the sacral outflow constitute a syetem that Innervate: the allmentury canal and parto developanentally connected wth 1t. Fe then divided the attonomic nervour aystem Intc toctal, bulboencral and sympthetle ayoted. Following the discovery that offects produced by adranalln were olmliar to those produced by etimiation of oympathetic nerves, and that certaln other aruga produced affecte Imilux to those produced by wtimulation of tectul and bulbosecxal nerve, he grouped the tectal and bulbosacral autonomile nervew together as the "parasymathetic" syaten $(1921)$. 16 Langley's claselfication of the nerves into autonould, srmpethetic and paragypathetle have been retained in present nomenckature.

By 1858, many antemtcal and phystologie atudies had been accolplished which lead to claude Bernard" alscovery of the vasomotor function of the sympachetic norves to the blood ressels. Thane early etudies of the vasonotor nerves gave rise to the ooncept of univereal vacoconstrietor aetion of eyapathetio nerva Libere. Bermard aleo cemonetrated the existenes of vasodilator nerves by stimiating the chorda typant resulting in dilatatlea of the arterles applying the submandibular gland. On the ballo of extensive physiological date, Bernard advanced the hypothenle that all eympathetic reflexes axa nediated through the eplnal cord and also denonstrated the oxiutence of centers in the brain atow which on etimulation diecharge Impulese that are condroted 
through symathetic nerves. The earch for higher centers which exert thelr infinence through the atconomic nerves as wall as intexast in deteraining the nervous wechaniawe operating in vasonotor and secretory control was thus inftiated.

The andemic alatribution of peripheral symatheties romalned to be desertbed for a thorough underatanding of vasomotor control of blood vessals. The innorvation of the blood reseols found by pay 21 ise and Bradford $(2894)^{5}$ Lnelnded efterent and efferent nerve fibare. The efferant nerves inelude both vacoonwexletor and vasodilator of whlch the former ere chlefiy aymathetle. The latter Inelude both sympathetle and parabympethetic componants. The existence of vasodilator flbers in oyapathetic nerves has been cenonstrated in exporimonts with animis and man. Lowla and Plokertng $(1932)^{\text {in }}$ in exporiments on humen eubjects demontrated vasodilatation by heating the aubject in waming chamber arranged so that the head and hands were unexposed and consequent warming of the body reavited in warming of the hands. The vasodilatation Involved in the warming of the hands, in thes expertmente, wo effected through the symathetle nerve: an Inclcated by the fact that warring of the body did not ellat similar responen in hands deprived of thels eympthetio innervation.

The aetion of the vasodilator nerven are studied on the pranlse that vaseconstrletion and vasodilatation are mediated by different neurohormonen. In general, the vamoconetrletor norva 
are adrenergic. The chollnorgle nature of the vasodilator flhara in the mueses of the bind liwb has been demonutrated in the cat 20 and in the $\operatorname{dog}^{21}$ by Folkcm. According to Folkow, in the dog and out the cutaneous nerve except in $11 \mathrm{mlted}$ areas, probably include no vaodilator fiber: A general dietribution of vasodilator flber in the cutaneovi nerves in mon hes not been demonetrated. Constrloting the cutaneous blood vesals with aronalin, as reported by Barerort ot al $(1947)^{3}$ ald not materially affect the increase in blood tow in the forearm caved by waxming the body. The increawed flow, therefore, wast have taken place in the macles. Thle respone was abollohed by aympthetie cenorvation of the extrentey. It mast, therefora, he mediated through vasodilator rellexes.

Iangley $(2077)^{43}$ ald many "ecretory" experiments in whlch he stimulated the "aympathetico" and the chorda tympan which lad to vasomotor studes in the feet of dogs, cats, and rabblte, defining far the firut time lovela of vasomotor outflow. Latex Baylis: and Bradford $(1894)^{5}$ reported a study on the innervation

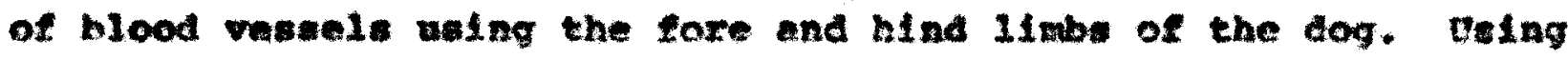
- voluw plethysmograph to record vaevular changes, he stimulated the peripheral ende of anterior and posterior roots of thoracte and Iumbar norves. Through this athod be was able to define phyalologie levels of vasomotor outflow tracti. However, asnce he atimulated both poaterior and anterior roots he was probably also getelng concomitant posterlor root vasodilatation throuph 
antidromic excitation. Baylin: lso demonstrated pronounced reelex vasoconetrietion of the hind limb upon stimulation of the central ond of the celatic nerve. Also, a pronounced pressor effect with pasalve dilatation of the hind liwb during tho excltation of the cotrel and of the alvided aplanchnle nerves occurred, therefore, amphaelalng the cact that one ahould bo cautious in Interpxeting vasomotor phenomenon as a manitentation of alreot efferent axcltation of peripheral aymathetio outflow.

The embryologlo devalopment of the autonomic ganglia and neurone have been studied extensively. The primordis of the autonomic ganglia axise early in embryonle development and are reIated developmentelly to the cerebroeplnal nervous system. Most of the early Inveatigators supported the theory that oell which nake up the primordis of the ganglia of the symathetic trunks and prevertebrel plexumes aro dexived axelusively from the epinal ganglla and neural ereete. Tunts (1909a) ${ }^{37}$ traced celle of madulIexy oxigin Iato the primordia of the sympathetie trunks via the ventral nerve roote and the combunloating raml and advanced the oplinion that the ayapathetie ganglion cells are derived chielly from the noural tube. He also demonstrated that autonomic gangil. bear the ane hietogenetic relationthip to the cerebroppinal nervous syoten in all classes of vertebrates. The dieplacoment of celle frem the nourel tube Into tho primordil of the autonomic gang11a both in the trunk and the head reglone has boen confirmad by numerous inventigatore. Jones $(1937)^{33}$ bas demonstrated in 
chlcke that only celle of modullary orlgin become afferentlated Into atconoric ganglion cells and that those whlch booone eympathetic and parasymathetio ganglion colls reapectively are displaced along the fiforent roots of the narves that convey the correaponding preganglionle outflow. This polnt of vilew that the ganglion ells present chiefly or exclusively cells that are aleplaced from the nearal tube along the pathe of ventral splnal nerve roota has been supported particularly by zuntz and anteon $(1920)^{38}$ and arizale and xunts $(1950)^{9}$.

The primordia of the gangl1a of the eyrupathetic trunks apparar earliest in the caudal thoracte and the rostral abdominal reglons. They are compoand of aggregates of cells of neural origin Iying along the dorsolateral apocts of the aorta. The egmental character of the eympthetic primordia gradually becomes apparent, as developant advances, and the coll aggregates become connected by longltudinal flbers. The primordia of the eympathetie trunik arise somewhat later in the corvical than in the thoracle region. In humane the pximordia of the ayepathetle trunk: grow cephalad in the cervical region both by the dieplacement of celle along the dorsal appects of the deacending aortae and by oell prolfferation. When segentation of these columne takes place, delimitation of the cervical syopathetio ganglia romulta. The gueation of development of autononlo ganglion from neural ereat was atudied by many experimenters and sturdel (1952) 61 traced cella from the neural tube along ventral nerve roote into 
the symathetic trank prtwoxala in chick enbryos in which the noural crest had been completely axclsed in a goxies of wegments. There vas no evtdence of noural arest dezlvative: in the regnonte In guostion. It was concluded that symathotis trunks may arise In complete absenco of calls derived fron the naral erest or the spinal ganglia ant that oalla of naral origin in the symathatio primordia must be derived axalusively from the neuxal tube along the vantral spinal nerve roots. The gact that wuch prinordis do not axtae in aegmenta in which the portion of the mantle layex that five fiae to the Intormadiolateral coll colum is deatroyed, auggeate that celis which enter the eympathetie primorala via the vantzal nerve roots, under normal condltions, are derived malnly from this portion of the neural tube. Brizale $(1949)^{10}$ demonetrated that nouroglial oelis in the oympathetle trunk ganglia aro doIvad partiy frow the neural creat $v i n$ the doreal roots and in paxt from the neural tube via the ventral norve roots and felt thexefore that oulla of noural orest origin that enter the sympathatia primorala can be acoounted for without tha assumption that any of thas becow Alferentiated into ganglion olle. Sohapar $(2897)^{58}$ in a cxition atudy of oell afferentiation in the cus, pointed out that the call which axtme by the altotio division of the "germinal" cell in the epandymal layer do not all beom nouroblasts. He deecrlbed tham as "Indifferent" cells, sone of which becose differentiated into nurons and other into neurog11a. Is also polnted out that in the higher vortobras, nayy of 
the Indifferent celle retain their capaetty for further differentiation by altotlc dividion and give rise to daghter oelle of the same Indifferent type whlch ay beoome diferentiated al thex Into neurons or into aupporting ealls. It may be wesubed, therefore, that many of the celle that becowe differontiated into narrone in the atonomic ganglion arlee by the mitotie divicion of algrant cell. Ither before or after they have becose incorporated in the primorula of those ganglion. The nourone in the avtonomic syeten, conmequenty, may be rognxded af homologow with the nouxons in the corebroppinal nervous eyetew. Howover, the gosetion of origln of avtonomic ganglion from neural creat or neural tube hae not yet boen seteled.

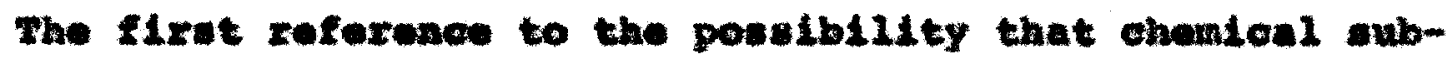
otenowe wigt be conoerned in the transalenion of axoltation from the notor-norve cexpinale to effector olle dates back to the

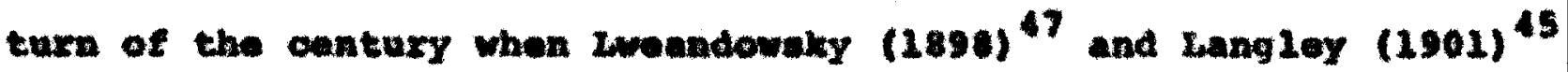

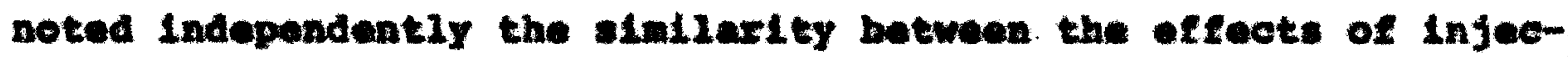
tion of axtragta of the adrenal gland and etimulation of arapathetle nerves. Whe brilliant reserrehes of otto lowi $(1921)^{49}$ onteblishod the elret real proet of the chemical modiction of

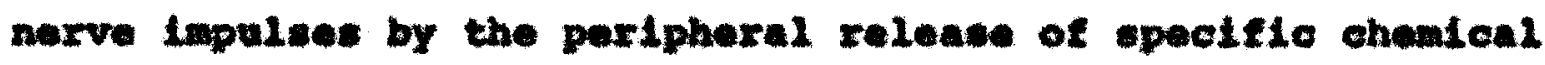
agents. Le etimulated the vague nerves of a perfueed (donor) frog hart and allowed the perfusion fluld to com in eontact with a cocond (realplent) frog haxt used as toat object. A subetunce was 1 lberated frow the elrst organ that slowed the rate 
of the second which he called "Vagusstoff" ("vagus abbeance", parasyapathin) which was subsequently lantilled as aedtylchoIIne. He also noted that an nocelerator abotance almilar to eplnephrine was Ilberated Into the perfusion eluld when the aotion of the ermpathetic fibers in the frog' a vague prodominated over that of the Inhibltory sibers. Many oubseguant inveotigator: establishod the fact that stiaulation of cranlosworal autonomic narves to smoth and cardiac muscle and to exoer Ino glands rosulted in the releave of a dnemical substance, acetylchollne, that coted upon effeotor colls to ellett their oharacteristic responsex:

In adaltion to 1 te rolo an the nourohumeral tranemitter of all postganglionic parabyapathetls llbexs and tew pontganglionle aypathetic flbers, ewch as those to the owat glands (Dal and Faldberg, 2934$)^{15}$ and the arapathetie vacodilator 14 bers (ivane, 1951) 62 , acetyloholine has been shown to have this transmittex function in three additional classes of norves 1) preganglionlo flber: of both gymathetic (Perry and raleanik, $1953)^{51}$ aystom, 2) motor nerves to akeletal muele (Dale et al, 1936) ${ }^{16}$, and 3$)$ certain neurons within the Cxs (Felaberg, 1950) ${ }^{19}$. Juet as there are blological Indlaters for the prenence of acetylcholine, thare axe speciflo test for detecting "sympthin". woh as accoleration of the rete of the dedervated heart, elevation of blood presaure, plloarection, inbibltion of intartinal museulature and relaxation of the denervated non-pregnant 


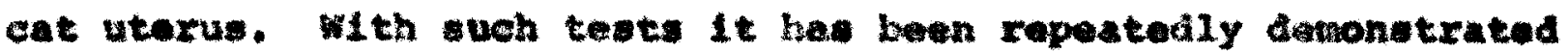
that when postganglionle armpathetie norves are atimulated there is released at the newroeftector junetiona a chomical subetance that has arapathouinatse proparties. For example, Bacq $(1931)^{2}$ found that stiundation of the cervioal sympathetic nerven caused the medlator to eppear in the aqueous hwoor of tin oye. Bargar and pale $(1910)^{4}$ noted that the effeote of eympathetio nerve atimilation were more closely reprodued by the injection of eympathoaimetio primary aminos than by that of epinephring or other secondary anines. Suler $(1946)^{18}$ found that the gyrogethomimatic abbtance in highly purifled extraots of sympathetio nerves and - ftector organa bore a strong recemblene to norwplnephrine by all orfterla used. No proposed that the oyapathetla transaltear Is noxmplnophrine and that eympathetie narve atimulation on eowe occanions way, In addition, 2lborate omil quantitie of eptnophthe Lseif.

Wh the advant of neurosurgleal techniques, moh intorast was placed on the antemial rolationwhip of sypathetle outflow to 1 es tunction. In order to Ineure permanent phyblologloal reaulte by syrupathotlo annervation, the surgleal procedure aust be anatomicaliy complote and oxrled out in such way that regenaration cannot tuke place. The quastion of vasemotor oontrol was of prime limportance in the rationale of sympathectomide in cextaln dicease proceseses and much lata on the vascrotar outflow systom comas frox exparimantal syryathotlo stimalation done on 
dogm and cats. In 1932, Buxn ${ }^{13}$, upon otimulating the lumbar aympathatle chain of the dog wile the hind limba were perfused with deflbrinated blood, found only a negliglble reapona. However, with the addition of adrenalline to the pertusate, the response to - ympathetic etimulation becase signifleant and was primarily one of ailatation and occanionally constriction, He also observed often an initlal vasodilatation convexting to vasoconstriction. Theae vasodilator responees to the atimulation of the sympathatic ehain in the dog vere obtained thout the ute of adrenergie blocking agents, and suggested the existence of a generallad ayntem of vasodilator flbers. These symathotio vasodilator 1 bers vere dewonetrated by Bulbring and Burn ${ }^{12}$ to be cholinergle and occurxed in the muedes. The dllator effecti vere augmented by eserine and abollahed by atropine. By volum pelthyamogrephic recordinge of the akinned hind Ilmb of the dog they demonstrated a dual Innervation of dog ruscle, both conetrletor and dilator. Folkow and co-workers ${ }^{22}$ in 1949 whlle working on the sympathetic vascomotor innervation of the skin of the dog found no evidence for the exlatence of vasodilator fibere to the akin of the doy hind Limb. In thase experlments only marked rasoconstriation was noted in the akin auring sympathetio atimulation. Green 30 . In a etudy of the antonomic control of blood flow in the hind paw of the dog, otfmulated the Iumbar aympathetlo chain and via alferential blockude of posalble adrenergte and chollnerglo mochanisus operating in the foot pad conoludad that the pay akin 
contalns abundant alphe oonetrictor recoptore, but very for 14 any adrenergle or chollnergla Allater reooptox:.

The guention of atconomil outflow pathways in the vasomotor control of perlpheral blocd vessels has been of great interemt to Investigatora primarily in the fleld of peripheral

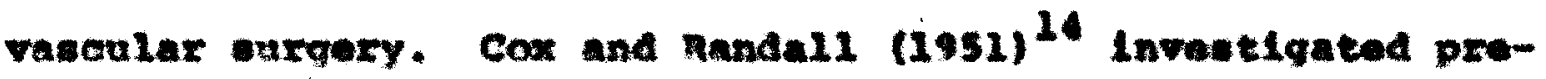
and postganglionie outflow of the ayputhotio trunk to the toot

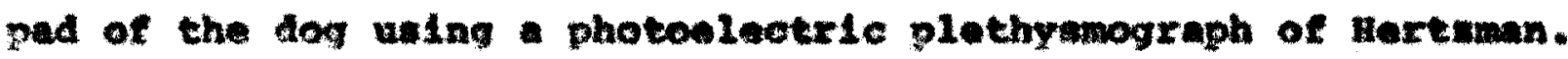
In the1r Investigation thay comonstrated a great variability in the leval of preganglionic inflow to the aypathetie trunk. surgleal intervantion has ben earried out not only on Iumbar oympethetice but on nearly all parte of the eymputhote systen. gurgary Involving the gyapathotio erunk has usanily consicted prinarly of oxtirpation of one or moxe ganglis with the Interventing intermodes. Equally complete functional aypathetle denorvation ahould be obtalned by wootlon of the pregan-

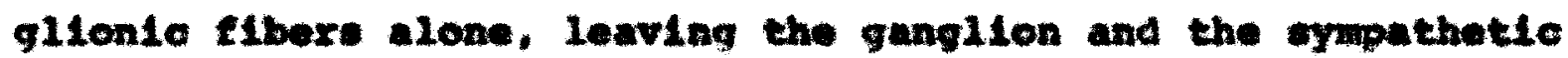
root: Inteat. Fregenglionte ympathectomy of this kind is nued by various aurgoons in order to avold censitization of the sympathetically denervated struetures to adxenis in the ofrculating blood. Howevar, contrary to current tenohing, not all peripheral oymathetic conduction pathway eravaran the syapathetic

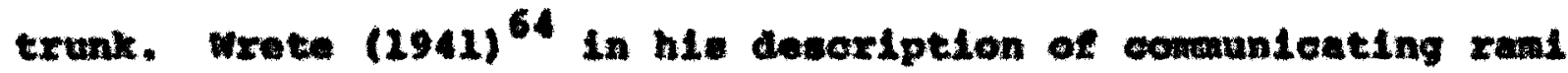
aeceribed groups of ganglion edis located in communtoating raml and symputhetic roote in the Inmbar roglon, and skoog $(1947)^{60}$ 
desertbed ganglia in the comanloating rami of the cervical ympathetio trunk. Wont of the ganglia reported have been loented In relation to symathotle roote and occaslonally have beon obcarved adjecant to aplnal nerves nenx the ortgin of the commancating rami. Both wrete and skoog have ouggostod the posalbility that in wow Inetances gangion cella located in relation to a epinal nerve way be oymaptleally related to preganglionia fibere that remoh them through the ventral root of the nerve and in turn send their axons distalward In tte perlpheral raml. sueb anatomlaul relationehip of ganglionle and preganglionle neurons woula rosult in porlphoral ampathetic oonduction pathweys which do not travaree the eymathetle truak. Therafora, conduction pathmays corwed in this wanner are not Intermpted by olther extirpation of the corramonding expments of the eyrpathetic trunk or action of the communleating ranl. Alexander et al $(1949)^{2}$ have obporvod aggregates of ganglion colls which may be callod coceneory oympathetlo ganglion, looted ajaeent to eplnal nerves or partially or completely anbedded in nerve trunke, uaually nent the ste of orlgin of the comunteating $x$ amus. Accesuory ganglla have aleo been obeerved in comanicating rant, usually near a oyppethetle trunk ganglion, In sypathetic roote and in ram that interoonnoet opinal norves. An aceecery ganglion located in a sypathetlo root probably recelves only preganglionic flbers that pase through eympathetle trunk. The postgangilonto fiber: that arteo in it joln the opinal nerve. Conduetion pethway formed in 
this annex, stnoe they traveree the aympathet1e trunk, do not differ essentidily from thoee with symaptio connection in oympathetle trunk ganglla. Therefore, the asenmption that the ascenvory ganglia, whlch are Intlmately associated wth eplnal nerve trunke, axe suffleloatly numerous and of ample magnitude to account for a relatively large number of sypathetle conduotion pathray not traverving the aypethatic trunk seome plassible. These acceswory ganglis probably subeerve wuch of the residual aypathetic aetivity that has ben dewonstrated in the corretponding dexmotomes zollowing extIrpation of the eympathete trunk.

In cervioul oypathoctondes the aevumption was made that the firet thoracte nerve played no signiflent part in the oyepathetle innervation of the uppar extromity. This aseupetion we eupperted by ceobogan ot al $(1942)^{28}$ wo found no pregangliente fibers for the hand in tho ventral roots rostral to the flret thoracte in monkers and third thoraole in the oat. Ray et al $(1943)^{36}$ studied chenged In cutanoow rosistenoe during ptimalation of ventral nerve roote of human subjects and roported preganglionic flbers for the hand pregent in the second to fleth thorale nerves. Kunte et al $(1938)^{39}$ found in otinum Inetion of ventral roote of the firet thoracte nerve vasoconatriotion in the distal parte of the Ilmb and activation of the oweat gland in the paw pada. However, the determination of preganglionle symathetle outhlow to the upper extrenlty remalned 
controveralal. Shewhn and $p 1$ ck $(1943)^{59}$ reported on the connection and conatitution of the raml comantcantes in the Rhesus nonkey. In this etudy, four general types of sympathetle branchen were Afferentlates accorilng to thelf fiber content. Typ I repreaents whte ramd, Types IIA and IIB, two varletles of grey ranl, Affering fron aseh other according to the number of Hine medullated Iber. contalned withln each, and Fype III wich ineluded the truly mixed cand. The tine nyelinated fibers (under 3 micron dimeter) which were present to some extent in all grey raml, occurred in particularly large numbers in the gray rami of $\mathrm{C}-\mathrm{s}$ and $\mathrm{T}-\mathrm{l}$ aplani nerves. Thelr abundance above the thoracolubar outflov otimulated further reasareh to deter-

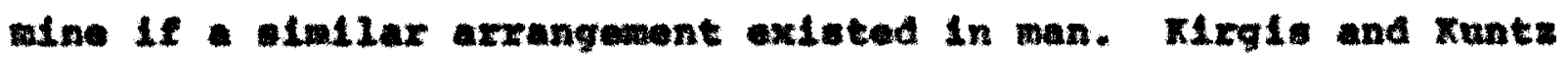
$(1942)^{36}$ reviewed the topographleal anatowy of the human aympathetle ohain and priwarily the cervieal reglon but there had been fow complete hletologleal Investlgatione roported as to the hlghert level of eympathatic outflow.

The firat etedy of the conetitution of the human sympethet1e rami, following the alecovery of the thoracolumber outtlow. was made by Haxwon $(1898-1900)^{31}$. Ueing the osmle acid ctaln on teawed preparations he examined only the rami of C-5 to $\mathrm{T}-4$ and $\mathrm{r}-11$ to $\mathrm{L}-4$ incluglvely. In the raxl of $\mathrm{C}-\mathrm{s}$ through C-8 and again at $L_{-3}$ to $L-5$ (1.2.. above and below the levels of eympathetic outflow) he oberved ayelinated flber: "under 4 microne in alameter* but nover more than 30 at any one oplnal 
level. Juba $(1930)^{34}$ uning welgert otalned material gave one of the few complete deseriptions of the constitution of the varlou rami of a tyapathetic branch examined in man. The wide dietribution of medullatod libor:, many of the amaller callber. within the rawl of the cervieal and lower lumbar nerves was very wident. The rand of the upper cervical regions ver noted to contaln wany finely wy LInated fiber: Plok and sheohan (1946) 29 studied the symathetio raml in men and observed frequent occurrence of pype e flbere lorey remi heavily "peppered" throughout Wth and medullated fibers under 3 micron diameter and ceveral hundred in number) in the rame of $c-7$ and $c-8$ and the vertebral nerve and again in the rami of $1-4,4-5$ and $5-1$, elgnifying the relative abundance at thee levele of flne myelinated flbers (under 3 mleron in dianeter). The lact that a imllar aletribution of thie type of grey rami existe in the cat and wonkey, Indicates some fundamental pattern, but wat lts Ignificance nay be Is not yet oleax. The nerves utudied were distributed partlcularly to the blood veseds and weat gland in the hand and foot, which axe notorloumly rich in thelr aymathetie innervation. They coneluded that the number of finely myelinated Lbare (under 3 micron. in alameter) within grey ranl have been greatly anderestimeted.

Regarding the uppar extremity, In rolation to residual sympathetlo pathways, there are atfexenoes of oplaton as to wat conetitutes a complete cenervation. The role of the first 
thoracle ventral root 1 a unsettled and ceohegan and Aldor (1942) 29 have demonetrated that a functional reorganiation may take place, reauleing in aypothetie activity through roota that previously ahowed no evidence of activity. Van zuakixin $(1941)^{63}$ has described, In humun enbryou, oympathetle thers whloh traverae as many as olx equments via nervea in the vertebral canal and kunt: and oillon $(1942)^{\text {to }}$ found evidence of oyapathetio aetivity atter sympathectany, wioh Ineluded atellate ganglionectory, attribueing rosidual activiey to thase flbers. Ray and Conwole (1948) ${ }^{55}$, whle studying reeldual pathway after apmpthactony conoluded that after exelelon of the paravertebral ganglionated chain, regaxd1ees of the axtent of the oxetelon, restaual eympethetie pathwyy which do not pane through any part of the paravertebral abaty remaln. Mfter parmvertabral oyapethectoay these pathway becomb andfect only after a procese of readjutenont takes place. ThoreLore, an Ineomplete denorvation may aimle conplete denervation for - portod of up to throe morthe, with returning oymathetio actiHty within this period due to readfuntwent and later return due to now mechentem, or to Investon by fibera from adjacent undenarvated areas. Ox regeneration. These conclusions may coovant In part for the inconsietent and translent reavite of eympatheotomy.

Mlexancer ot al $(1949)^{2}$ in revlentag lallures to echleve complet ympatbetic denervation, particulariy in the extrenites, by artirpation of the appropriete anpate of the ampathetic 
trunke or by coctlon of the white conanderting rant of the appropriate egmente, have also anggented the poselble exlstence of peripheral aymptbetic conduetion pathway which do not traveree the syapathetle trunk. Such pathways oould be postulated on the aseumption that come abryonle nerve olle, In thelr dieplacement from the neural tube, have falled to reach the primorala of the sympathetle tranke and have been diffexentiated into ganglion calle In the ventral norve roote, ox adjacent to then, where they

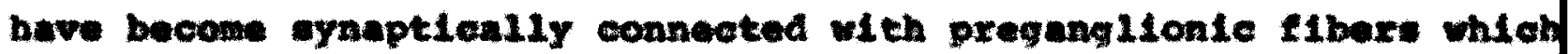
1thex do not extend into the ayaphthetio trunk or give oft oollaterale to the ganglion ouls in quention. In thelr examination of a cortes of human bodies, they obemrved amall genglia abodaled In ventral aerve roote or ajgeont to thom, uounlly at the alte or oxigin of a mite communleating ramus and in communicating rant, particularly grey ramt. Piok $(1957)^{52}$ on reviewing the

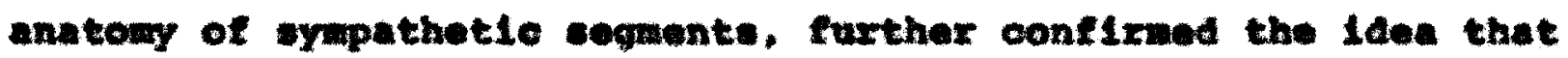
syapes of pre- and poetgengilonie tibere are not alwaye contined to the gang 11a of the aypathetie truak, but it may be alfted, - Ither distally forming an Intermedlary ganglia on the groy ramu or proximally onto the white rawus as suggeated by skoog $(1947)^{60}$. Ehrlieh and Mlexander $(2951)^{27}$ undertook further stendies on the avryteal Implloatlons of upper thoracle ladependent eympathetio pathwy in ordar to obtaln additional data relative to the cecurrence of accessory sympthetle ganglione in wan and the ix anatomie relationshlpe to the lower carvical and thoreale opinal 
nerves, and their elgnifienuce in the oympathetic innervation of the upper extrendty. They found frequent oocurrence of accessery ganglion of whlch most, ameept thome ansoclated wth grey comunloating raml of mpapathete roote, are oynaptloally related to proganglionic fibers whloh reach thew alrectly through the ventral nerve roote. Thele axons in turn extending distalward in momelic raml of the oplnal nerves forming eympathetic eonduction pathwaye not traversing aymathetle trunk. Ray $(1993)^{57}$ vpon xeviewing the effectrenes: of oymathectony of the uppex extremity concluded from the accundating bulk of dat reviewed, that the

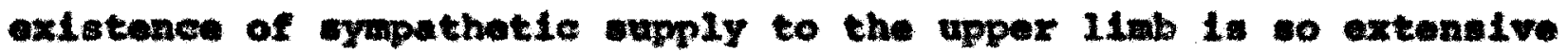
that no practloal oporation, ither preganglionic or postgang11onle alowe or in comblnation, an bo relled upen to affect an aboolutely oomlete denervation. In this artiole fay refuted the thoory that aenelelzatlon and rogeneration nooounted for raturn of aymathete tone to denervated areas and conflrmed the ldea of aceeacory aympathetie gangilon.

boyd and Nonxo $(1949)^{6}$ atimulated by the observation of "ovdowator enoupe" areas, areas of meating pattern following

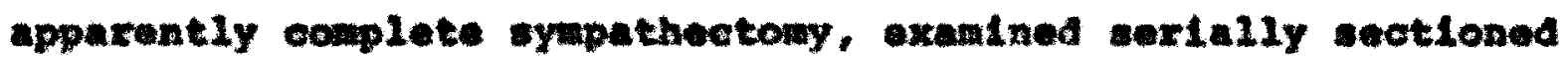
buann eabryos and fetuas in an attempt to locete syapathetle celle which wovld acoount for resteun pathway to the aweat glands not ramoved in thoracolvabar sympathectomy. This Inventigation rovealod the presence of numeroue- and oonetantly pronent (though varlable in nubler and stuation)- attonomie cella and 


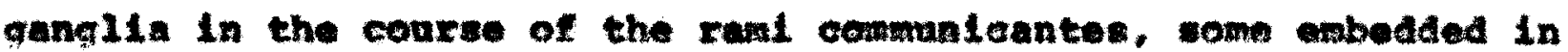
and some on the atureca of the wentrnl primary rant of the lumbar norves. boyd $(2937)^{7}$ elaborated furthex on the aceeseory sympthotic ganglis and folt for the mont part they are to be found on the couras of the ranl comunileantes and wost comon on the postgangllonle or grey rami. Howver, the proganglionle connactione of the cella of the acoaseoxy gennlion have not beon definttely ontabliwhed. For the cervleal necessory qanglia the preganglionIo outelow in not conolusive but boyd foels its likoly that most of the progenglionto tibers pase up in the corvieal chain. In the cervieal region the aceesmory ganglia appear to ba moxe widely diepered and in acveral embryos, Boyd has cound ganglionie aggrepatlons in the lower servial nerves as they pasi betwean the seaIene waskde on thelr wry to the brachlal plexws. Several courees for the preganglionie fibere to the accessory ganglion have been suggested. For the cello stuated in splnal norver contalning a pregunglionle outrlow it is coneluded that the preganglionie connection ia reatrioted to that norve. It was thoughe that all preganglionie apply to the cervical avessory ganglion reaches the oel1s of the ganglion via cervionl paravertebral ohain but, the complientions of the ragton introduced by the presenes of the vertebral nerve, or nerves, by the presence of the ana subelarla, by the erequent atypical arxangemente of the aympathetic chain in tront of the flrat ribo made an andyals of the cervieal region alfflevit. Thorefors, In the corvical replon at leate wome of 
the syapathetle flbere way eseape in corvioothoracle eympathectomy.

Pinally, the peraletence of Intact aymathetie celis with their postganglionic flbers doubtlesely explains wany of the functlonal regenerative phonowenon following oympathectodios. The anatomieal altuation any be such that sectoned preg nglionic isbar: can readily extend into the rogion containing the interwediate gang110n. A1so, Murray and mompson $(1957)^{50}$ hapo angested that functional reorganization, poselbiy by tho developaent of collateral eproute, can oscux after aysathectowy. This raisen the poselbility that percisting intermediate ganglion way be of Importance in proviaing the powtganglionle pathway if functional contact with these coll. Is made by ouch oollateral oprotes.

Kuntz et al $(1956)^{42}$ atudied the nerve flbex components of

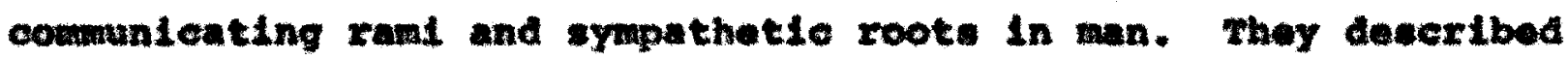

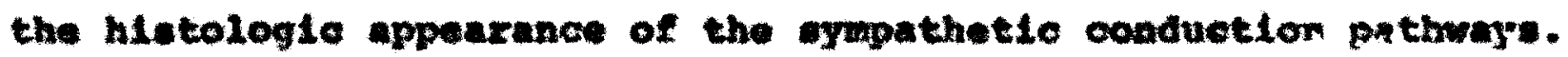
The preganglionle components arlating from the ventral splnal nerve

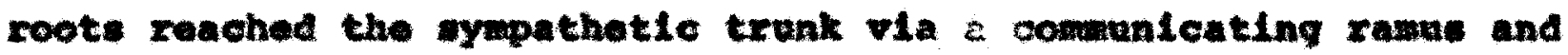
hietologlonily tell into the dianeter range of leas than $1-3.5$ plarons. The clbere vithin this dimeter range wore found to be

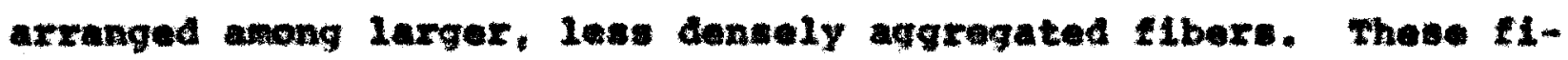
ber: were found as hlgh as C-8. Hietologie examination of artal longltedinel aectione of cympethetlc root: in 5 human cadavera revealed acoessory ganglion oils freguently in those nerves that make up the bxachlal plexuev. Ganglion oell In sympathetlc 
roots or adjecent to them occur in mall and large aqgregates. Most of them are Incorporated in compact ganglion. Most preganglionic flbars thet make symaptic connections with accewery ganglion cells located in relation to sympathetic roots undoubtedly travarwe these roots to polnte where the ganglion colls are 10cetad. Hyelinated flber within the progenglionle calibor range,

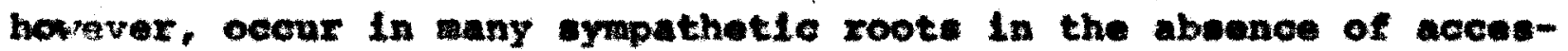
eory ganglion cella. In addition to sympathotic roote the oympa-

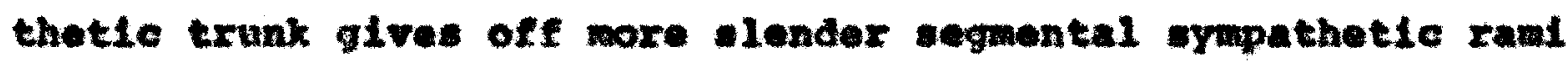
which do not joln the apinal nexves. In the corvical segmente som of theas raml join the plexue of the earotld and vertebral arteries contributing to their Imervation. If is felt, that mowt of the proganglionle flbere that make erpaptic connection: wth ganglion oelle that are located in proximity to segmental nerve: probably do not traverae oymathetic rooto, but rench the colis In question through oegmental rami from the syapathetio trank.

Data relative to the rontral inft of the outrlow of preganglionic Ilbers conoerned with armpathatlo Innervation of the upper extremity axe inoonolualve. On the basis of digltal rawomotor reaponse: to etinulation of the ventral nerve roote in man, exposed during operative procedures, bxidges and Yohr $(1955)^{8}$ coneluded that in addition to lower thorecle nerve roota, the ventral roote of both the firet thoraelo and alghth cervioal nerves are traversed by preganglionlo elbare that are concerned 
with the vamomotor Innervation of the hand. Noffman $(1957)^{32}$ In an andyele of the sympethetio trank and rami in corvical rom glons of man observed the occurrence of acceseory ganglion colla throughout the entlre cervical symathetie trunk not previousiy reported. A2so, he observed the presence of laxge numbers of myelinated fiber: that do not excesd 3.5 microne in alameter in the vertobral nerve supporting the concluaton of nomo Investigatora that thia nerve represents an accessory syrophetio trunk. on histologio section tho large number of myelinated fibere in the dianoter range of preganglionic flbers found in the vertebral nerve suggests that ganglion colln mat be present in conslderable abundance. Lotfan obeerved that the cervical and rostral thoracle symathete root inelude myelinated fibers, most of which are lose than 4 atcrone in diameter and are particularly abundant in the ventral roots of the alxth, seventh, and olghth cervical nerves. Hoffmen then concluded that the rostral Iinct of the preganglionlc outelow In man appears to be at leat an high aw the Ighth cervical segment.

It It clear from the above reviow of 11 terature that the upper limt of the preganglionic ayapathetle outelow is not elentIy underatood. 


\section{MPTODS AND MATERALS}

The following experimente were executed uelng 24 young mongrel doge to determine if pregangilonic outflow from the cervieal apinel cord could be domonstrated. Only young dog: ware used whone avarage izes ranged from 3-8 k1lograms, and only thone wty tender, non-calloused wht te pawa, beesune of the dependence on light reflection for recording of a volume pule through a photoalectric plethyamograph. The doge ware first anowthetized with alphamohlorolose, the action of which induced anesthesia by central depreselon without a reppiratory or cardlovascular depressLon under thexapeutle dosage (1 oc/ $\mathrm{kg}$ ). A tracheotomy wus cone and postelve proseure resplrator attached. The Innex thigh was shavec, fenoral artery was exposed and cathoter was then introm duced Into the artery and connected to statham pressure tran:ducer and bloed preseure recorded vis a model 5 grase polygraph. Wext. the back was maved from the ocelpltal protuberance to the level of the fourth thoracte eptne and a miline Ineteion made frow the spine of the axis to the oplne of the third thorae10 vertebre. The mascle meses overiylng the opines of the cervieal vertebrae wore weparated ualng a voldering gun with a modHed onteing head and all bleedere canterized. The cervioul 
aplnes wers atripped of their perlostenl and IIgmentoua attachaents exposing the lamina and articular processes as far a the third thoracle vertebrae. A laninectomy was done and the fifth cervical to the second thoracle epinal level wera exposed. The front paw wa then cleaned and photo lectric plethyavograph was ttmohed to the laxge central pad to measure cutanoous volume pulses. To attach the photonlectric detector to cutaneous areas, a thin layer of mineral oll is firat placed on the face of the photoce11, In oxter to Increase light tranamission and greatiy Improve the performance of the detector. The detector is then held Irmiy agalnet the central pad by a lat, wide rubber band Ath hol cat out whoh fits anugly around the detectors eaning. siver roll wa then wrapped around the detector in order to avold any interterenee from axtraneove light sources. The minlaturlacd

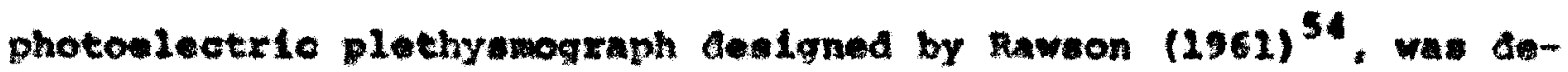
algned for recording, through capact tanoe coupling, pulatelle blood tow ohangen in vasular bed.

5inee we are interested in the pulsatile changes in the cutaneous vaseels, mention should bo made of experimentation wth the plethyamograph by Raweon $(1961)^{54}$. In his research he denon-trated that although the IIIunination from the photoelectrio cell penetrated the skin, the layor of fasol separating skin from mascle pmoldad auflelent impodence to the 11ght to prevent vascular ohanges in the musele fror affeoting the cutaneoum record. The changes recordad as paleations axe due to altexation in 
abeorptian of light quantitativaly ralated to lnerease and decrease In blood volume of the vasculez bed with each pulse. Therefore, channga related to eympathetle vasoconetrietion an be demonetrated by the changas as recorded from the front paw. Noxt, masoular hlockerte was induced by Decamethontum, Which nots to produce a paralys of atriated muscle by depolariation of the motor on plate thont cauding qanglionte paralysis. A unipoline alectrode was attmehed to a Grass motel 3c atfmulator and gromien to retractor. The atimulator was

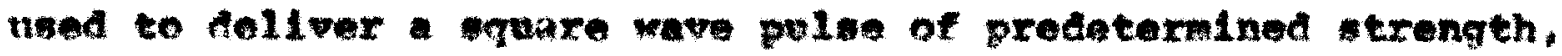
duration and erequenoy. The parmetera for atimulating the antartor and posterinr ronts for optimum etimulation of sympathete tibers has been deterrilned on the basis of Bronk et al (1936) tho cemonetrated a dinchnres rate of about 1 to 3 Impalses per accond in "resting" lanlated sympthetle flbers and by polkew $(1952)^{23}$ wo demonatrated that normal conatrictor tone it maintalned by an ectivity of only 1 to 2 impulaed por ceond. The dscharge of flber at maximal phyalological exctetion from the vasometor center wa evtlmated not to exceed 10 impulnee per secona. Rendall et al $(1953)^{53}$, wh12 atudylng the vescotor Innervation of the $\mathrm{og}^{\prime}$ " hind foot pud determined the optimum paraweter. for aympathetic trunk atimulation. These apeciflc otimulating parameter were wed in the present experimental procedures. The paraneters ued for etimulation were follow: trequency of 10 cycles per secona, duration of 5111 ieconds, and roltage 
of 5 valt.

the segment of enterlor ent posterior root wers care-

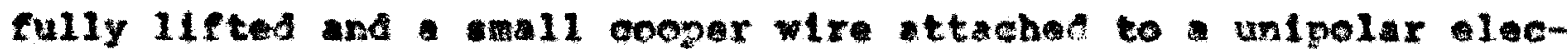
trode was placed around the Intact roots. Mirmaral oll was then usta to flocd the area to betimulated, therofore avolalng any conduetion through the mediua. spresd of current, if it ocourred, was detestall by a waxp axop in the stimulating potential observed on the oscliloscope. The oxcllioscope was also used to cheok the frequency and duration of the atiulating pulas and the voltage sattinge vere checked agalnst atangard cell. Both the anterlor and poeterlor roots veroguntially atiwulated in the Intact condition from the elghth cervical roots cophalad through the fieth cervical roots. Then each root was wectoned and their Alstal ends restimulated uning the van paranoters in order to rule out an reflex effect. Freman at a $(1950)^{24}$ whll studyIng afferent therg in portpherel oympethetio nerves and funte (1951) ${ }^{11}$ in revieving the afferent Innervation of paripharal

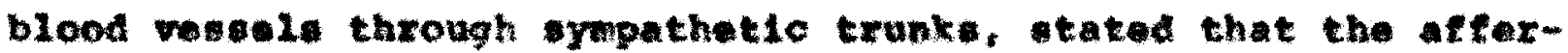

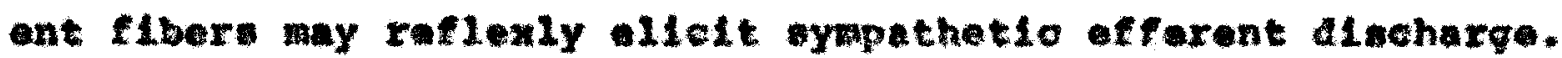
Kerelake $(1951)^{35}$ reported on the abolition of reflex vasodilam tation of the hand, ane to heating of tho foot and leg. by oym patheatory of the heated 11wb. Therefore, by eliminating the posible reflex efrect: via the spinal cord or by conduction along the mediun, an accurate Interpretation of aymathetically -11cited vanomotor activity of the front paw wa observed. The 
Eympthetle responses vere recordad on aodel 5 erame polygraph. Imadilately following ctimulation, the anterlor and posterlor root from the elghth cervieal to the elech cervienl segmant vere removed for determination histologleally of preganglionle uymathetle flbere. Lech root was out to about 12 man Ingtha and placed in flxing colution. The seotlons wex fixed in boscatro Linative, a combination of gwa chloral hrdzate, 100 ce distiled water, 100 oo of 95 aloohol and 3 co of nitrio achd. ChLoral hydrate wes beed as eixing agent in olther water or alcohol. but wavily in water-aloohol mixture and has a opectele applieation in the fixation of nervous tiaste. In Its action It

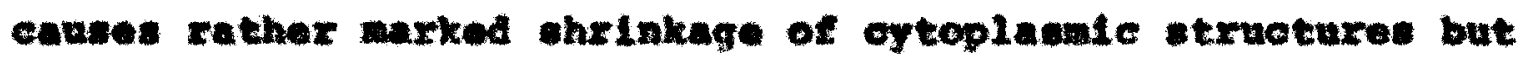
gives rather good prestrvation of the general topographie cher-

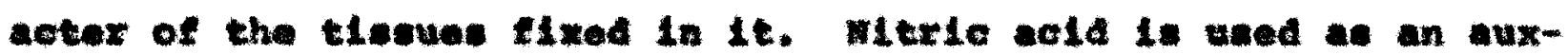
1114ery agent which anhance the etreot of chlormi hydrate in Alation of the tisewe. The tiseves were then placed in the cold at 4 dogrees contlgrad. tor 24 hour:, allowing onough time tor thorough ponetration and reaction with the tiseves. The tiseu was then wabho in altellied vater via a disyrer for 24 hour: ahonglag the water 3 times during the proeass. Following aldiyats of coluble materiale frow the roote, the procese of blook stalning was begun.

The tiseve wa placed in amoniated aloohol (50 ec absoIute alcohol and 3 drop of ammonlun hydroxide) for 1 to 2 day". In order to move the balk of the ayelin from the nervous tiane 
and thereby faclitate penatration by the IIvar solutions. Noxt, the tiasue vas placed into 26 colution of slver mitrate in an oven at 37 degrees contlgrate for $41 / 2$ to 5 days. During this perlod the nervoua tlasue becones lapregnated with oliver. In order that a metallio compoind may be usable fox staining, it gast be readily convertible to an Ineoluble reaction product. The reduetion of the Aliver nitrate ls brought about by a reduclag solution composed of 1 gu of pyrogallic acld, 92 ce of vater and ce (37) formaldahyde. The reduction process was carried out for 24 hours in the dark, alnes the affect of Ilght during alvering I the Impalzment of the alectivity of the atain for noural elements. Fismue was then dehydrated by proper tochnique and ambedded In 61 degraes paraftin whlch affords an excellent supporting medium to the Intersticas of the block of tiseve for adecquate sectioning. The sections were cut at 12 mit thleknes: and mounted on sllde: using eqg albomin. Nervo flbers (axons) stalned grey to black mile connective tianue etalned black. The sections were then exaninad fox preganglionte myapthetio tiber: using a dameter size of 3 mierons or lest as our criteria and a eaction frow the aecond thoracte root as a standurd. The roots were counted ueing a calibratad grid for meanuring diandeter alze. 


\section{RESULTs}

1. Cardiovascular response to electical stinulation of ventral roots of cervioul cord: In the course of this research a total of 14 doge were aployed. The firet five experimantal animals were aubjected to a unllateral sympthectomy, uning a transthoracle approach. The ith rib was resected, the pleara Inciaed and Iungs retracted anteriorly. The stellate ganglion

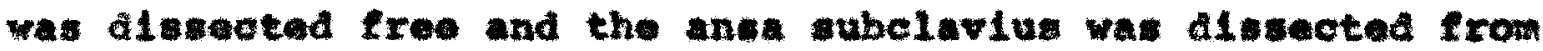
axound the subelavian artery as well as the branchen axising cephalad from the stellate. The caudal corvical ganglion was Alssected free and soparted from the vagomerapathet1c trunk. The sympthetic erunk wa then disuected free as low as the fourth thoracio leval and the aymathetlc ganglia and trunk reacoved. The reasoning bohind the gympthectomies was based on prior laminectomies in which vasoconetriction occurred in the foot pad of the dog ouring the wryery and ald not reopen. Therafore, it was felt that symatheotomy before ventral root atrulation should permit recording of adequate roluwe pulses and facliltate recording of vasoconetrietlvo responsed during root stlalation. Rowever, in rotrospect it wean that by removing aympathetle ganglion we vere removing the mott probable 
souxce of armaptes for preganglionlo outflow. Thase animale ware absequentiy subjocted to lamineetomy and the ventral roots of the corvical cord ware then atimuletas sequentialiy from the elghth cervical through the fitth cervical level. Because of the surgloal mortality and lack of positive rompones to etimulation, the sympathectomias were diseontinued. The following nine experimental animale were then operated on, dolng direot ventral root atimulation followin laminectony whout prior aympathectobies. In dogs number 8 and 9 transection of the cord at $\mathrm{C}-8$ - T-1 was sone in order to rule out central effects of electral etimulation.

Nine doge qave negative findinge and of those exhlbiting poultive ramults, dog number sovealed the wost definite positive findings, Reault of ctirulating the ventral roots of cer rioal nerves of dog numbar axe choun in lqure 1. The upper tracting is record of femoral arterial preasure that how relatively large oscllitions armebronous with the postefve pres-

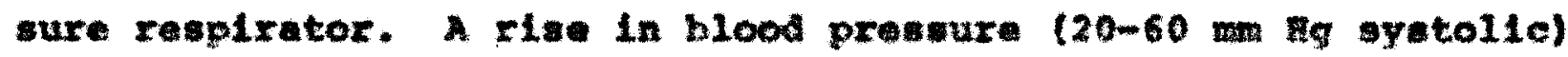
and marked Increase in heart rate $(60-100 / \mathrm{m} / \mathrm{n})$ during ach stimulation may be notod. There vas a gradation in response, the loast belng ellolted by etimiation at the fifth cervioal level and the greateet at the eventh and elghth cervical lovel. Oneet of the remponse was proapt (within 3-5 secondi) and recovery was complete approximately $30-45$ seconds after ceasation of atinulation. Bectioning of the splnal cord between the efghth 

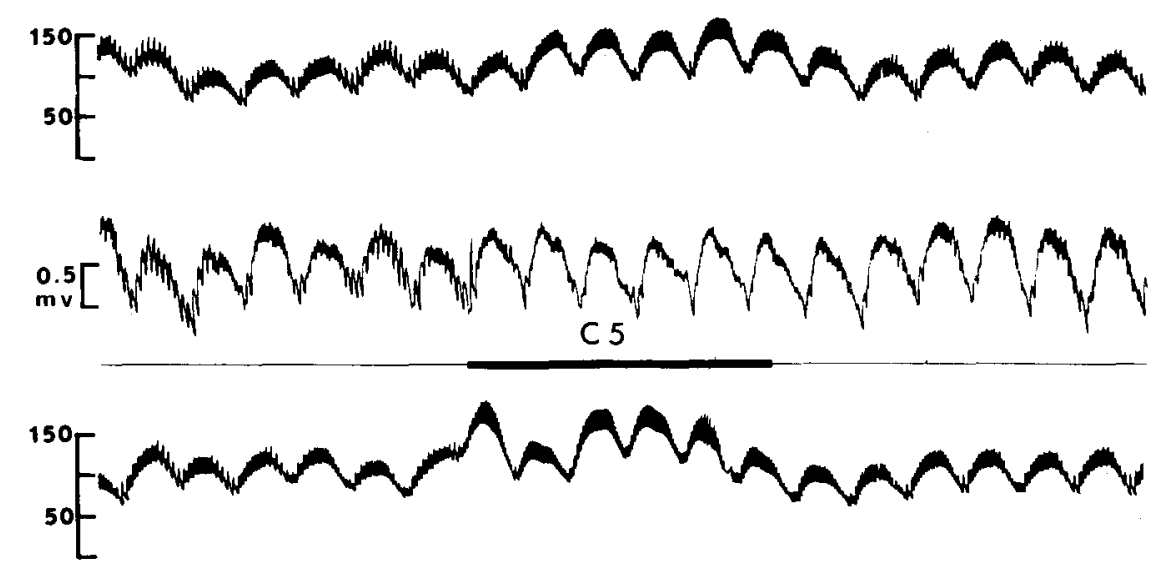

${ }_{m=5}^{0.5}$

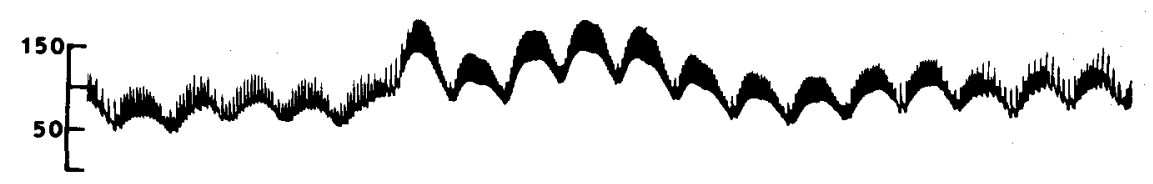

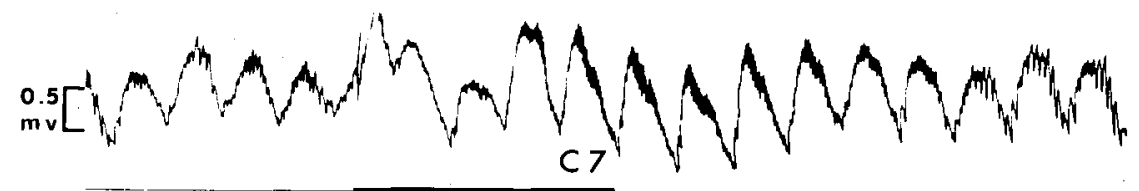

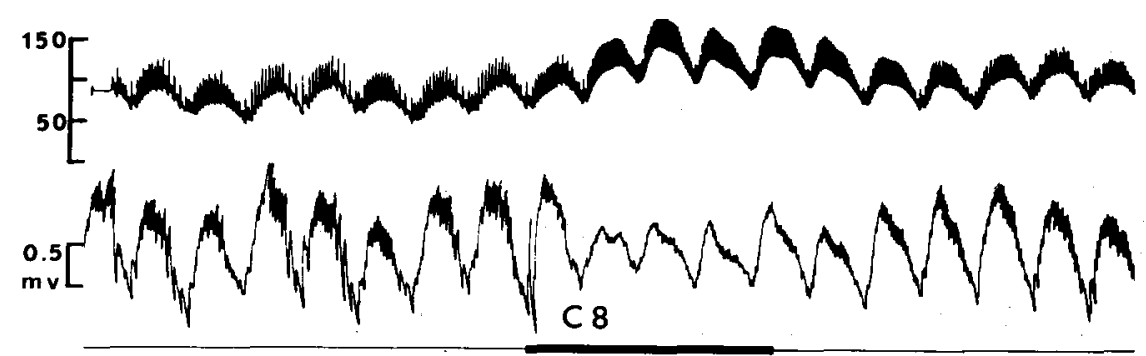

Frovre 1

Animal Number ${ }^{*}$ Reaulte of stimulation of ventral roote of corvical nexven C5, C6, C7, and Ca. Uppor tracing, blood prensure: middle tracing, cutaneons volume pulan: and bottem line, time of atimalation. Paper apeed, $21 / 2 \mathrm{ma} / \mathrm{sec}$. 
oervical and frot thoracle segwent did not prevent the response. The lower tracing of each palr of records shows the changes In pulse amplitude in the foot pad. Decrease in amplitude It due to vasoconstriction and decreased volume of blood flow through the root pad durling ench pulse. The blood preseure response and augrantation of heart rate and vasoconstriction of outaneous pulse can be regarded as Indicative of prequnglionle eympathetio outfion. response to lectrienl etiwulatien in the ventral roots of the cervical norves. The rasults in Flgure 1 are these following etimulation of anterior roots after the anterior and poeterior roote were sectional. Sectioning of the oplual cord betwen the elghth cervioal and first thoredo ogment did not provent tho response.

The reanlte following transection of cord at $c-9-\mathrm{T}-1$ level can be seen In Figure 2 and 3 . Migure 2 Le from exporimontal animul numbex in wheh prlor to transection of the cord positive findinge were recorded (FIgure 1). Following transection. a definite augmentation of heart rate is apparent in the lower tracing, but withont the conconltant rive In B.P. or peripheral vasoconetriction. Dewplte the lack of vasoconetriotive effect or B.P. Elae, the lact thet the auguentation of heart rate occuxxod, an effect coneldered eympathetio in origin, would geem to refute any possibl11ty of retrograde atimalation of descending sympathetlc libers through the opinal cord. The recording repreeate atimulation of the distal and of the ventral root of c-a, 


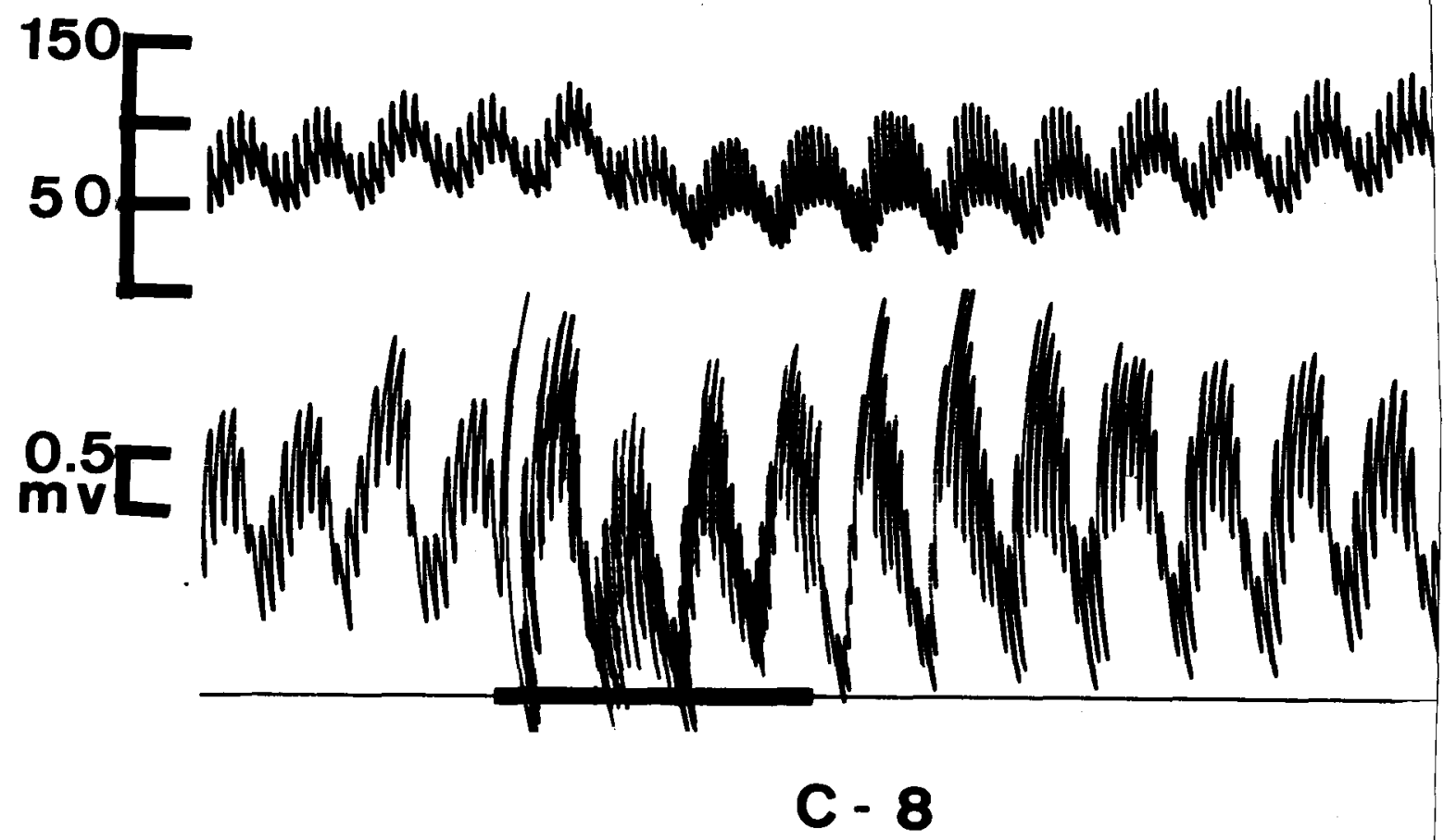

FTERT 2

Animal truber 8 : Reoult: of the etimulation of ventral root of the elghth corvieal morve efter transection of the apinal cord at c-om-1. Uppor tracting, blood preseure and heart xuter middie traclag, cutaneous volume pules; and bottom Ilne, tine of atimulation. Paper apead, $21 / 2 \mathrm{~mm} / \mathrm{eec}$. 

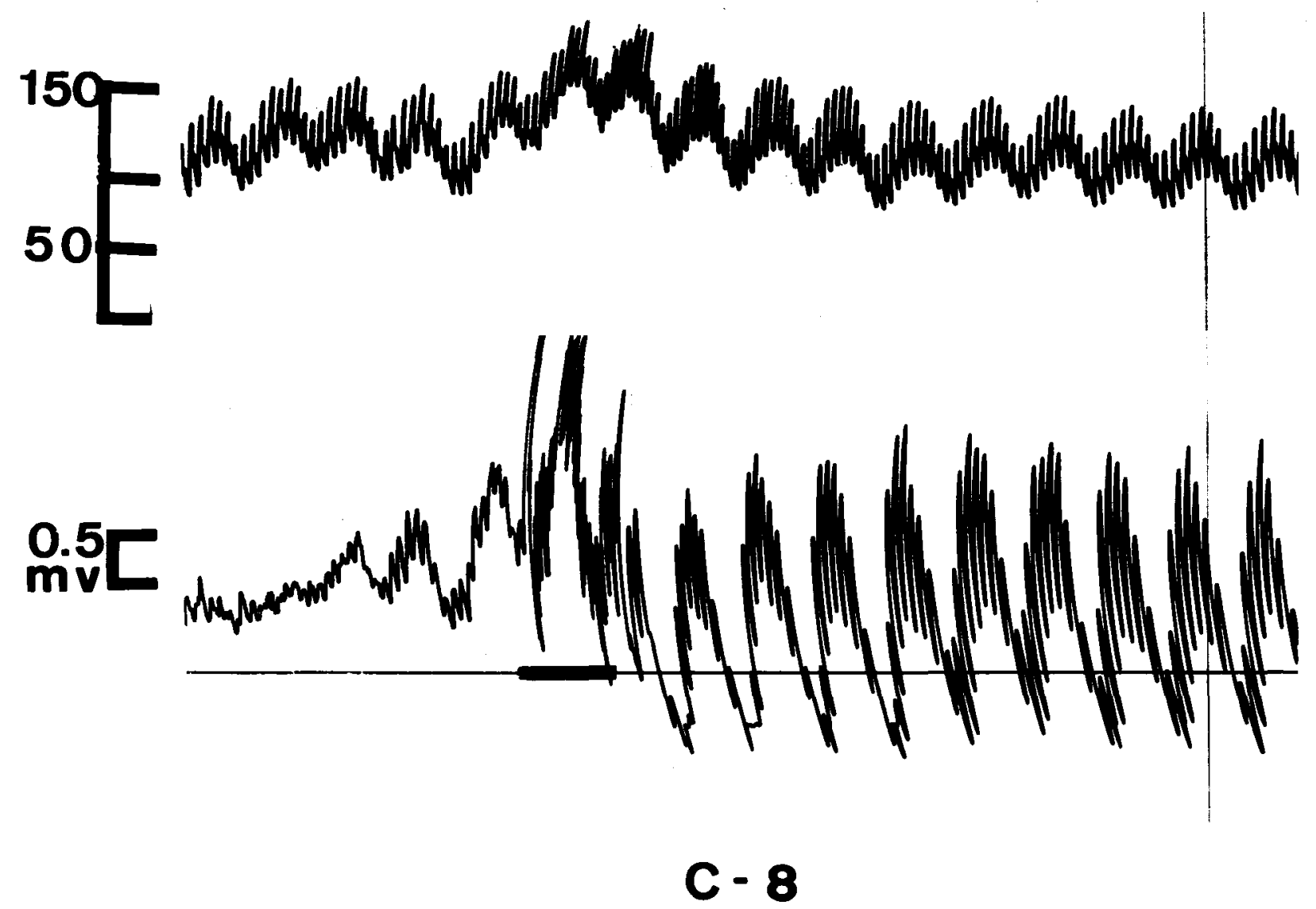

\section{PTOURE 3}

Animal Number 9 . Revulte of the ctimulation of ventral root of the afghth cerviteal nerve after traneection of the opinel cort

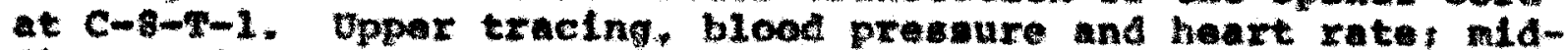
die tracing, cataneous volume palse and bottom itne, time of stimulation. Paper speec, 2 1/2 mo/senc. 
at whloh tirae the distal root was held up away from any adjacent geructures and then strulated. Aleo, Figure 3 represents the ane procedure, In which the diteal and of C-g of animal number 9 wan atimulated following tramsection of the cord at C- $-\mathrm{T}-1$. In this otimulation, augmentation of $\mathrm{M}$.R. Was recorded as well a rise in E.P. In the lower tracing. Again, no partpheral vasoconstrictive reaponse wa seon. Thes findings correlate well wth these in Figuxe in which inflar cardlovaseular flndinge oceurred pxlor to transection of cora.

Flqure 1 is from a 4 Kg lemale (animal number 9) in which the distal end: of proviously eut vantral roots from c-6 through C-8 were etimulated and again demonstrated in the lower tracing the blood preseure rive (20-50 ma fystelle) and augrentation of heart rate $(60-100 / \mathrm{m}(\mathrm{n})$ as noted in Plgure 1 . The lover tracing of weh palr of records again domonetrated ohanges in the pula amplitude in the foot pad a expected if aymathetio outflow Io present.

Flguxe 5 is angle tracing duxing alectrlesl stimulation of the elghth cervioal root of a $31 / 2 \mathrm{~kg}$ mid (animal number 13) in which onjy vasoconatriction was noted (lowex tracing) wthout the conoomitant changea in blood preseure and heart rate. The probable axplantelon for lack of blood preneure and heart rate changes 11 in the work of wrete $(1941)^{64}$ and skoog $(1947)^{60}$ who described some accesmory gangl1: which way 11. within ox adjecent to spinal norves. In these caces 

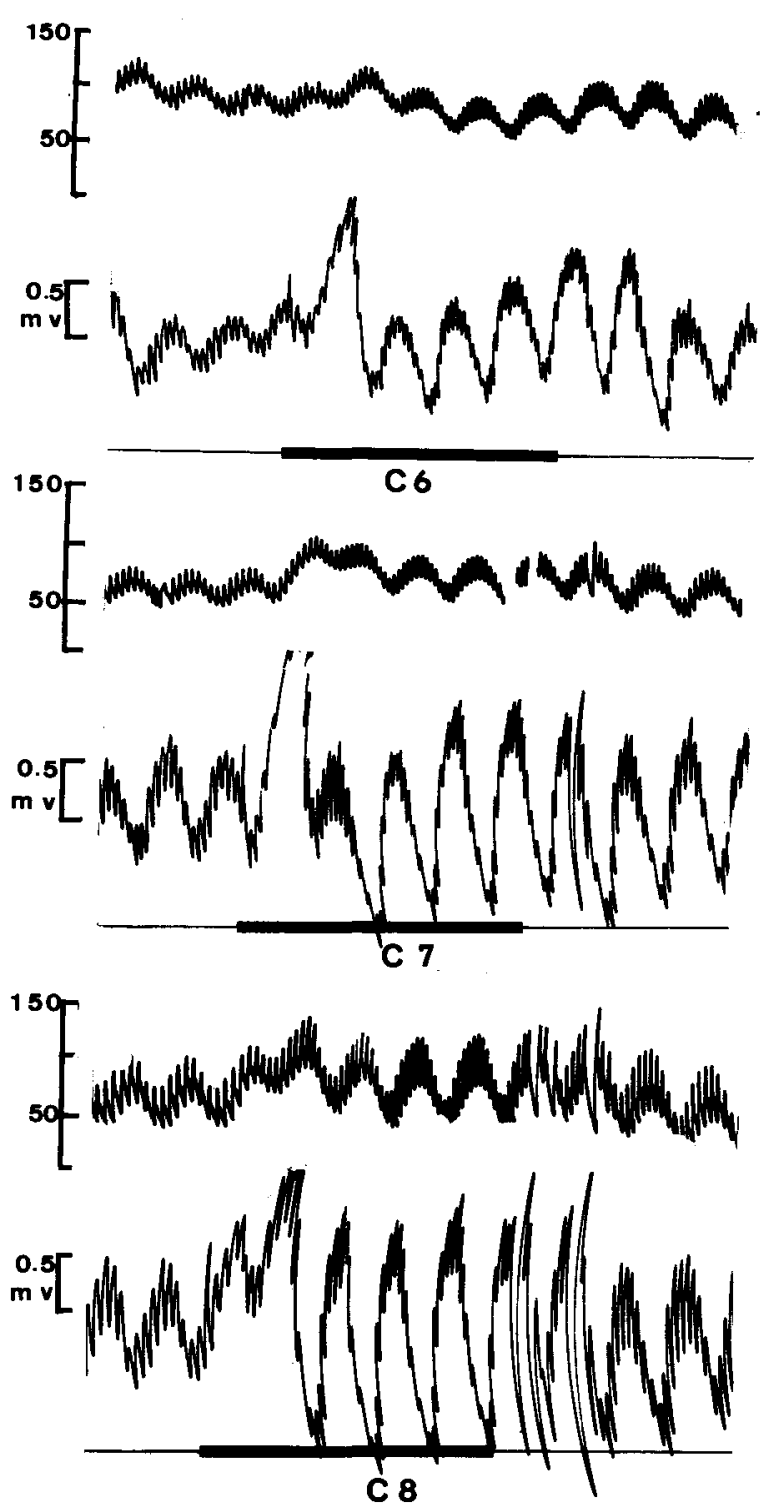

raver 4

Antmal Tumber 9, Results of atimulation of ventral root of $c 6$, C7, and c8 cervical nerven, upper tracing, blood preasure, niddie tracing. blooa llow lower line, the of etimulation. 


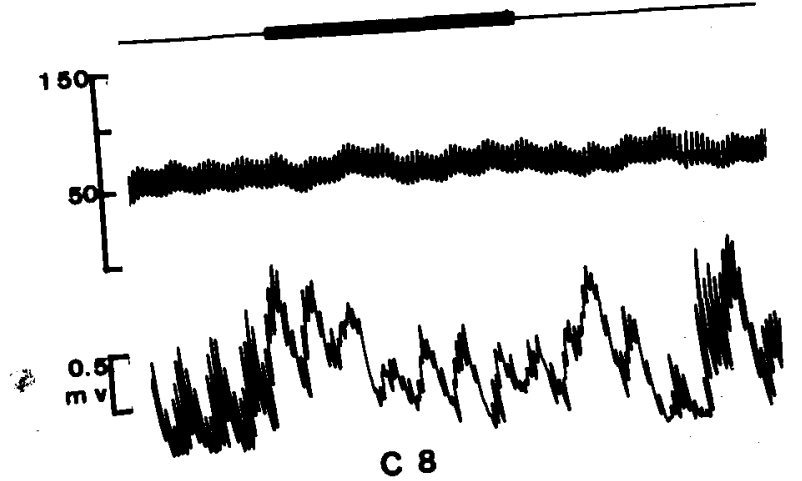

\section{TOURE 5}

Animal tumber 13: Resules of ctimulation of ventral root of - lohth cervieal nerve upper 1ine, tine of etimulation midd1. tracing, blood presure, lower traclng, blood flow. paper spoed $21 / 2 \mathrm{~mm} / \mathrm{sec}$. 
proganglinnte flbers ayapse directly wh the acoessory ganglia bypasing the cervioul ganglia and continuing dietulward along the oourse of the nerve. In this ene only vaecoonstriction would be the affact of etimilation, whereas, 1t the pregang11-

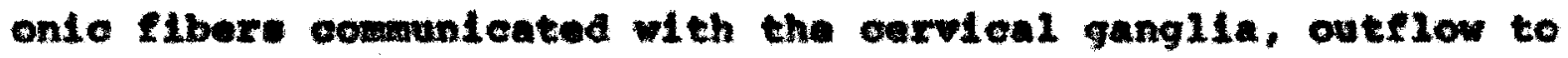
the hast and abbequent angmentation of heart rate and blood Llow would be exhibited.

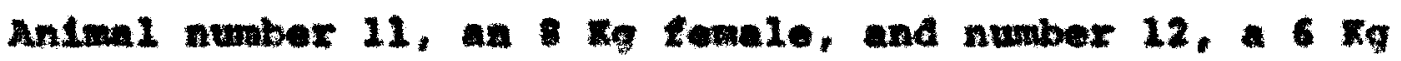
female, alto shoved inllar changee in blood tlow, blood preacuxe, and heart rate af desexibed in Plgures 1-5.

Table I represente a tablation of effect of alectrical stimulation on hoart rate, blood promsure and velume pulae in $\$ 1114$ doge netmalated.

Dog: nuaber 1 through number 5 were (1rat ayapatheoto-

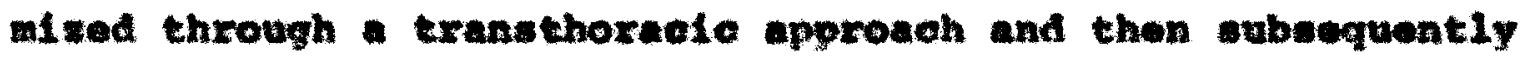
operated on two aly later and tholr vantral roote ctinulated. Doga number 1 through number 3 died prior to or during lamin-ctemy procedure dog numbr iled of mesthetio overdoes: and dog nwmber 5 was unable to colerate leminectomy and aled

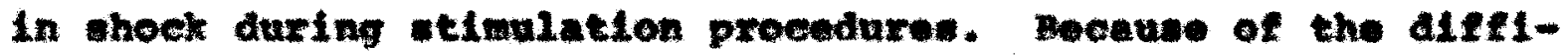
culties and poor tolarence of the expoximental animale to two agquential major surgleal proosdures. It was dectad that ventral root etimulation alone would be done taking precaution: to aseure that rocorilng of opeclele ventral root etimulation: could be varifled (reter to disouesion). Doge number 6 and 
Tatre I

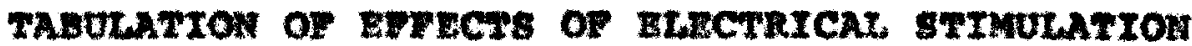

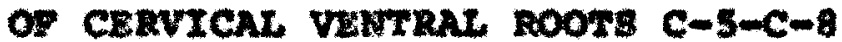

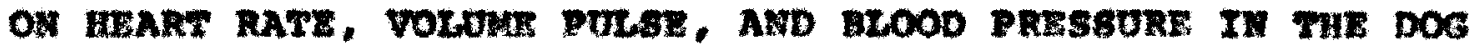

\begin{tabular}{|c|c|c|c|c|c|c|c|c|c|c|c|c|}
\hline \multirow[t]{2}{*}{$\begin{array}{l}\text { An ima } 1 \\
\text { number }\end{array}$} & \multicolumn{4}{|c|}{$\begin{array}{l}\text { Change in } \\
\text { geart gete }\end{array}$} & \multicolumn{4}{|c|}{$\begin{array}{c}\text { Change in } \\
\text { Volmae palse }\end{array}$} & \multicolumn{4}{|c|}{$\begin{array}{c}\text { Change in } \\
\text { eloos preepure }\end{array}$} \\
\hline & $10-5$ & 6 & 7 & 8 & $c-5$ & 6 & 7 & 8 & $c-5$ & 6 & 7 & 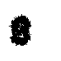 \\
\hline
\end{tabular}

Reaulte In Syopathectonl wod Mimals

\begin{tabular}{|c|c|c|c|c|c|c|c|c|c|c|c|c|}
\hline 1 & ac & we & WC & we & we & $\mathrm{Nc}$ & we & we & the & we & ne & ac \\
\hline 2 & nc & We & ne & ne & ace & ac & HC & xe & ate & ac & nc & nc \\
\hline 3 & ne & ne & $\mathrm{nc}$ & tre & ne & ne & ne & ve & me & ne & we & uc \\
\hline 4 & we & we & are & ne & uc & inc & Ne & ne & We & ac & nc & nc \\
\hline 5 & ac & we & We & we & we & ne & wc & ace & ne & ne & ne & ac \\
\hline
\end{tabular}

Reovite in Non-Syepathectondzed Animal.

\begin{tabular}{|c|c|c|c|c|c|c|c|c|c|c|c|c|}
\hline 6 & nc & ne & $\mathrm{Nc}$ & nc & we & He & We & are & wC & wc & ne & we \\
\hline 7 & ne & We & ac & ne & we & ne & we & nc & Me & ne & we & we \\
\hline$\theta$ & 4 & $\uparrow$ & $\uparrow$ & 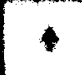 & $\downarrow$ & + & $\downarrow$ & $\downarrow$ & 1 & + & 4 & + \\
\hline 9 & ne & $\downarrow$ & $\bullet$ & 4 & ne & + & + & 4 & $\mathrm{NC}$ & 4 & 4 & 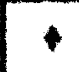 \\
\hline 10 & we & he & we & we & wc & wC & ne & ac & we & nc & nc & ne \\
\hline 11 & uec & + & 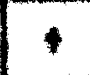 & 4 & ne & $\bullet$ & $\downarrow$ & 4 & we & + & 4 & $\uparrow$ \\
\hline 12 & we & $\uparrow$ & 4 & 4 & ne & $\downarrow$ & + & $\downarrow$ & $\mathrm{MC}$ & 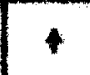 & $\rightarrow$ & + \\
\hline 23 & we & Mc & ne & we & ace & we & ne & + & ne & ne & $\mathrm{NC}$ & uc \\
\hline 14 & we & ne & ne & we & we & $\mathrm{Ne}$ & $m c$ & ve & sec & we & we & Ne \\
\hline
\end{tabular}

tiegulte of stimulation of the Elghth Ventral noot Aeter Tranaection of cord Batween $C-8-\mathrm{T}-1$

\begin{tabular}{|c|c|c|c|c|c|c|c|c|c|c|c|c|}
\hline 8 & 4 & $\uparrow$ & + & 4 & ne & rec & we & wec & we & Inc & we & we \\
\hline 9 & 4 & 4 & 4 & 4 & Ne & we & we & ace & 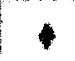 & 4 & 4 & $\uparrow$ \\
\hline
\end{tabular}




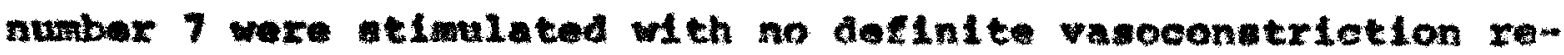
sponse or blood pressure changes being recorded. Doge number 10 and number 14 exhiblted almilar nagative remponses. The emplantelon for the lack of aympethotic roopones may be cue to the alffioulty in recording ohanges In the cutaneous pulso beomase of a coomcelloved ontral pad. Also, nolwe within the electrionl equipment did not afford good atandard pulse prior to welmalation. Miso, alno orapathotic outeiow in the oertion moote are varlabie, the posibility oxisto that in the dogs with negative flndings cexvieal aympathetio outelow wee not present.

II. nistelogieal andyels of cervical anterlor roota Preganglionle symathetle axons are and myelineted libers from 1-3 mlexons in diangtex. If such fibera are prevont in the ventral roots of corvieal norves, approprlataly etalned

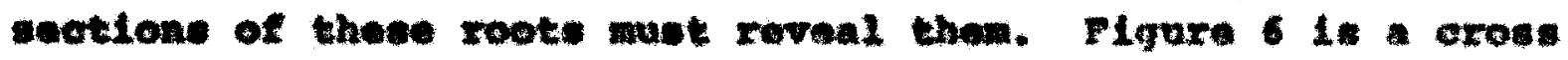
section of the seventh corvical ventral root of the dog which was stimulated to produce the functional responsos shom in Plgure 1 (C7 stimulation). The photonfexograph raveals nu-

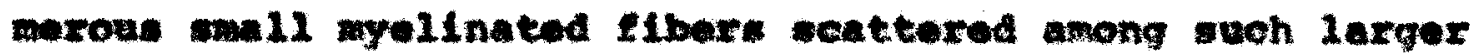
and hoavily myelinated motor axons. When measured on the 10 mieron een1e Ineludia in photograph, it is apparant that thoge

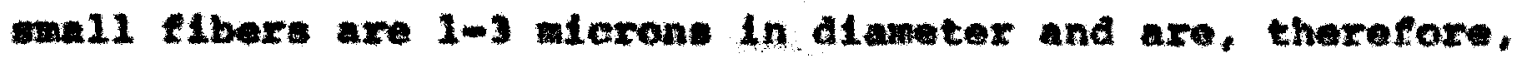
of the appropriate ste to be olacelfled as aypathetic preganglionie flber: Although at Irat glance the large notor 


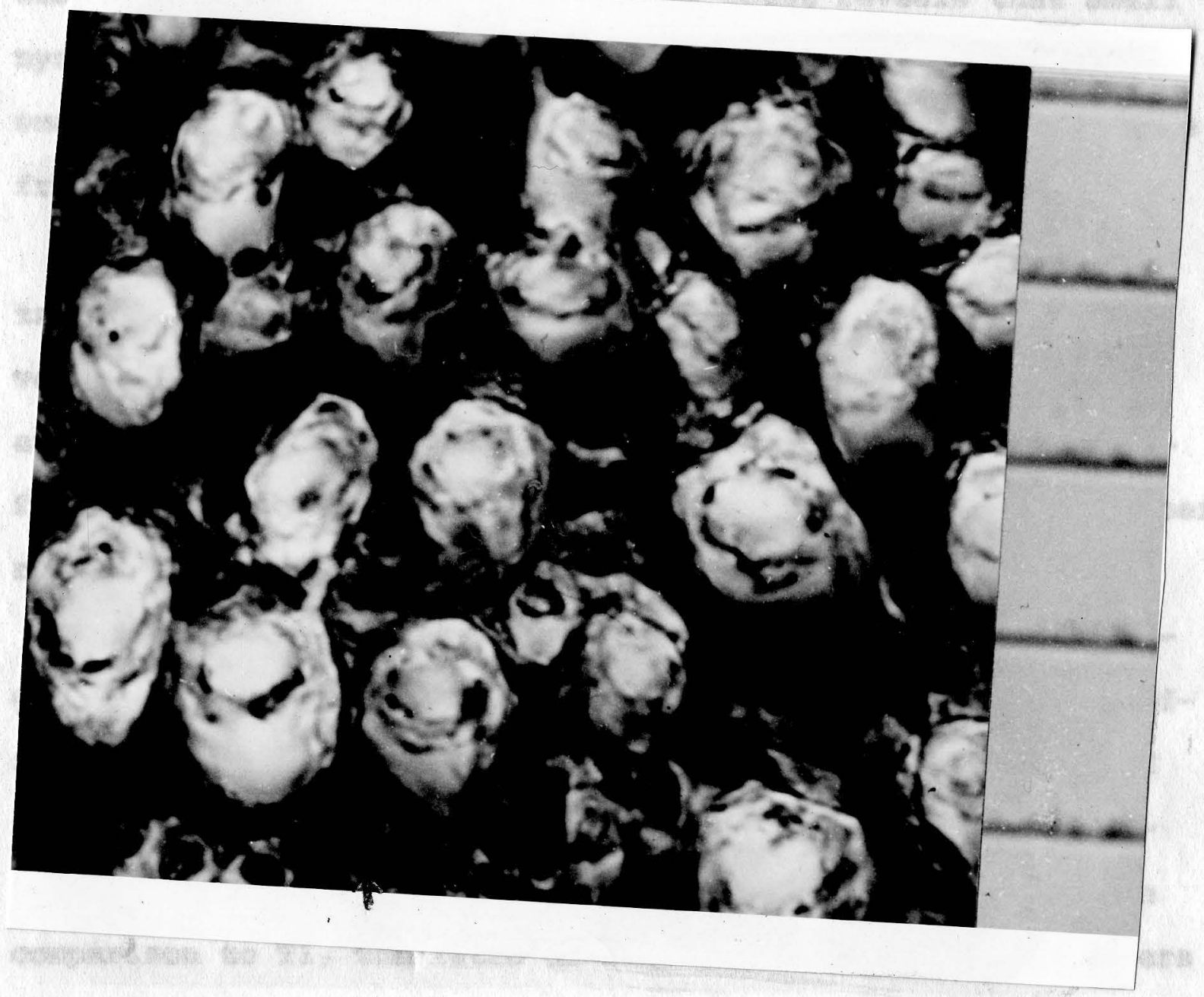

FxGUR: 6

Animal thuber a cross section of ventzal root C7 fron experimental animal of Figure 1. A modifled Decastro technigue was used. Scale, 10 microns between 11nes. Arrow incteates typleal 3 mieron diameter fibers which were found consistentiy in C5, C6, and $\mathrm{Cs}$ of the saxo expertuental animal. 
Llber seen more numorous, an actual count raveals that amall myelinated elbers outnumber large onen lout 3,1 . sintlar gnall Llbers ware found seaterad throughout the sections made Iron ventral reots of CS, c6, and ce nerves, (Table II)

Flgure 7 is arose section of the lirat thoracie ventral root taken from the ane animal as in P1gure 6, and zaveal. the expocted laxye popalation of onall, thinly myelinated flbera. The photomlerograph was wade at the same nagniflention as thet in Flquxe 6, and comparteon of the omall fibers

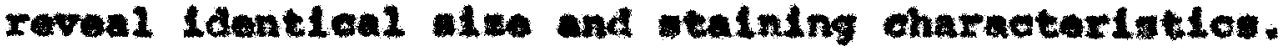

rable II represente roulte of diroct oouting of proganglionie oympathatie fibers in otalnad actions of five alffarent animale. A grid callbrated to 3 mlorone was amployed In mosuring dLameter el so of nerve axons and an entire section of ventral root wa counted at oach oorvieal lovel. In

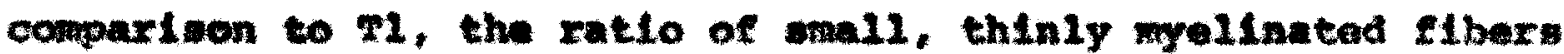
(preganglionic sympathet(a) in corvical to thoraclo level was ahout 1:3, an adequate number to account for aymathetic aponass reosrat on etimulation.

Exper Lmental andmalo weh negative reulte physlologically were not stalned and coctioned. In retroapect, these tisaves should have been sectionen since the postbility of Individual variation in flber number may acoount for the lack of postelve finding:

rom the preceding resulta on can see that the 


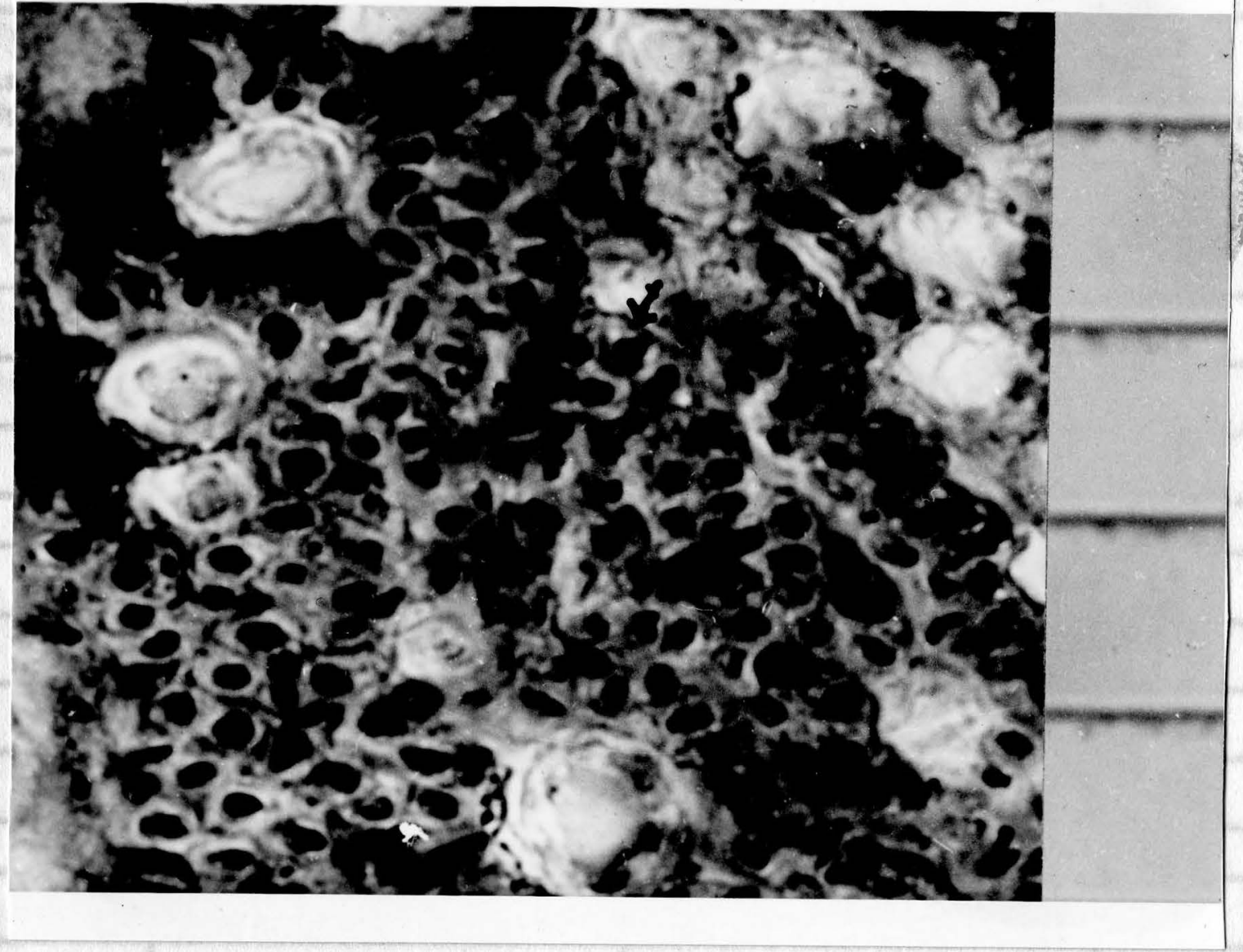

Exavras 7

Anima2 Number 8: Crose section of vertzal, root ri frov experimental animal of plgure 1. Seale, 10 micxons between 11 nos. nrrow indicates typica. 3 aicron almatex preganglionic aymathetle flbers found consistently in the thoracic level of all dogs and 1dentleal to flbers founc in Figure 6 . 


\section{TARE IT}

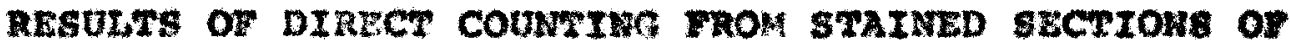

CERVICAL ROONS FOK PREOAnGuTONIC SYMPATHATC FIBsRs

\begin{tabular}{|c|c|c|c|}
\hline Antma 1 & $\begin{array}{l}\text { Lowed of } \\
\text { Vantral Root }\end{array}$ & $\begin{array}{c}\text { Number of } \\
3 \text { Merren or Lane } \\
\text { Iborm/Nentral Root }\end{array}$ & Atherage \\
\hline 9 & 31 & 2950 & \\
\hline 9 & $c 5$ & 1496 & \\
\hline- & cs & 641 & \\
\hline $\mathbf{1 1}$ & $\mathrm{cs}$ & 595 & \\
\hline 12 & C5 & 2312 & 1010 \\
\hline 8 & 66 & 939 & \\
\hline 9 & $\mathrm{co}$ & 1200 & \\
\hline 11 & ca & 750 & \\
\hline 12 & $\mathrm{co}$ & 1536 & 1128 \\
\hline
\end{tabular}

\begin{tabular}{c|c|c|c}
\hline 9 & $c 7$ & 847 & \\
\hline 9 & $c 7$ & 1378 & \\
\hline 11 & $c 7$ & 703 & \\
\hline 12 & $c 7$ & 1331 & 1065 \\
\hline
\end{tabular}

\begin{tabular}{c|c|c|c}
\hline 8 & $c 8$ & 774 & \\
\hline 9 & $c 8$ & 764 & \\
\hline 11 & $c 8$ & 867 & \\
\hline 12 & $c 8$ & 1142 & \\
\hline 13 & $c 8$ & 155 & 1020 \\
\hline
\end{tabular}


4

physiological result of atimiating the ventral roots of $\mathrm{CS}$ through $C 8$ in some case result in vasoconstriction of cutsnoun blood vessels. The anatomical endings of pregnellonic sympathetic fibers correlate well with the physlologloal at foot. The presence of preganalionle sympathetic fibers in cs through cs would bang up the question of presence of similar fiber in cl through ch. Much work repenting to be done in the Investigation of cervical sympathetic outflow pathway, not only in the tog, but in other animals also. 


\section{DIscussroN}

since the advent of autonomid neuromurgery, the question of aberrant pathways or acceseory sympathet1c gang11a has baen brought up in an attempt to explatn the lack of aucceas in surqical sympathectory for the rellet of certain vasompantic alseases. Although palt 1 iterature reveals extensive work polnting out phytologle ovldance of mymathet1c outflow as high at the - lght cervical level and wany author have demongtrated proganglionic elber in the comanlcating rant of symathetic roots as hlgh as the sixth carvical level, no experiment have been con In which morphologle and physlologic data, through atimalatlon of the cervionl roots of doge from C-5 through $C-8$, has been precented demonstrating preganglionle aymathetic outfiow in the carvical roote of the dog.

The anatomical ovidence for the presence of oymathetic vasomotor flbero in the carvieal anterlor roots were roported

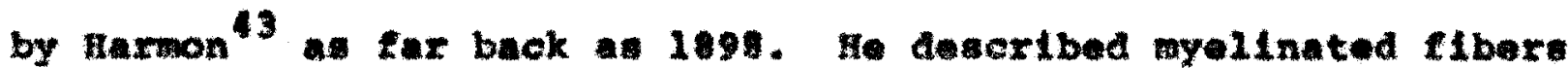
under micron in diameter in the symathotlc rant of C-5 through C-8 and plok and sheohan ${ }^{45}$ observed many linely myelinated 3 alcron dianeter fibers within the groy raxil of $c-7$ and $c-8$. In wy resulta after actioning the anterior root: of $\mathrm{C}-5,6,7$, and 


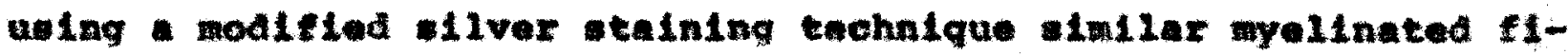
bors emaliex then 3 mlerone in diamater were lentified, and by Alrect counting technique were lound to be present in a ratio of about 311 In compartion to larqer fibers. These libere are histologically claselfled a preganglionic syapathetios and aro ldenteal to preganglionice found in the anterior roote at tho thoracle levalu of the ane animals. These findinge vould ceen to be In agreament with Kuntz ot $a^{55}$ who noted the frequent oecurrence of accascory gangl1a colle in sympthetio roots or in olose proxInlty therefore aftording on explanation for the occurrence of preganglionte tibers in the ame sympathetle roote. They dos-

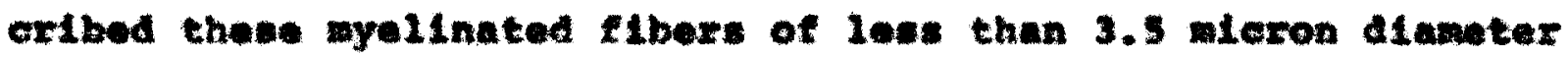
In ayapathetlo roota an high as C-6. Also, by comparing actual counts of the cotal number of aggrogated fibere in a rentral root and the elber. in the alaweter range of preganglionle tibers in the oommantenting ramo arielng from the norve, there ras a relaEvely close correapondence. Therefore, It appoured hlghly probable that the proganglienle flber: foand in the oownunicating ramue traverse the ventral root: of the aam nerve.

The abeve morphologle elndinge correlate wall with the phyelologle phase of the expertmant. In the phyelologio phase, ventral roote of $c-5$ through $c-8$ wexe exposed and stlmulated. Opon seimulation of these ventral roots in several dog recortIng: of decreased cutaneous blood rolum was used as a criterla for any vawoonstrictive effoets. Folkow et al whlle studying 
cutanoous blood low in man demonstrated that vasoconstriction of the cutaneous blood vesed. In san i: purely ormpathetio in

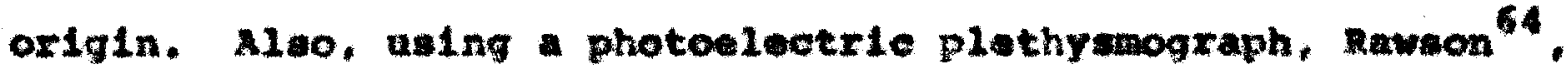
was able to record only vasoular chenges in the cutaneoug blood veasels. Upon stimulation of the ventral roots of c-s through C-8 in evveral doge vasosonstriction was definitely recorded. In the light of polkow et $\mathrm{I}^{\mathrm{B}}$ the vasoconstrictiva affects of -timulation can only be conoluded an aypathetlo activity. From the IIght of Rawson's experirents 64 we can alwo conclude that only cutaneous vamoconetriction and not muscular contraction

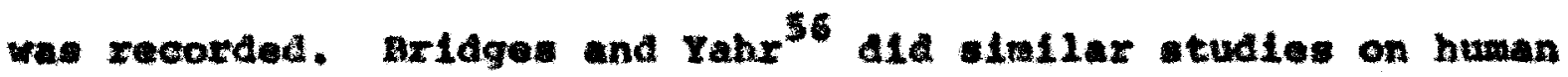
abjects stimulating the anterlor roots and racording digltal vanoconstriction as high as thi elghth cervical levale. No attempt was made to atimulate anterior roots any higher than C-8 and no other reports of ench otimulation has been ctean in the Ilterature. The potentially compllcating factor of mucle movemant was obviated by the uec of Decamethonitu, ate re1axant. Control experimants were cone in which the ventral roote were stimulated wthout Deowathoniw and recordings were unreliable because of the excessive muscular activity of the doge Iimb. When Decarethonium was adminiatered a conalatent reooraing of the volume pulme was maintalnad. The question of eentral effect: was obviated by stimulating the ventral root: while intact and then cutting and stlublating the distal end. Stallar recordings resulted from otimulation of intact or distal ends of 


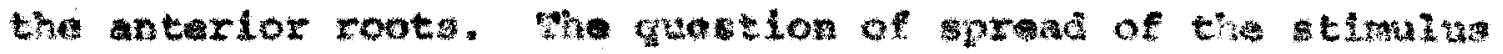
through the dum was avoldad by flooding the area with mineral 011. Having twken these precautions, the rasults of the timulation could only be via the roots stimulated. thus, onclude that in the Ifght of oux regearch thare are preganglionle efferent outflow above the claseleal level of T-1 in our expeximental dogs. The algnifleance of our flndings can be understood in the 11ght of nunerous fallure: in attengted syapathectonles for vasospat lo Alwewses. Our flnding would acoount in some caves for the observation of audomotor activity In patient: with corvical transuction of the oplnal cora. Also, In stellate ganglloneotomies oux findings would account for the lack of a Norner" ayndrome following thls procedure. 


\section{SUMARRY MD CONCLOSION}

The following conclusions pertinent to the study of oervical aympthetle outelow in the dog hava been Aram:

1. Phyalologie eridenow of proganglionic aympathetio outflow vla the vontral reote of $C-5$ through $c-8$ has been demonatrated by outanepus vanoconetrietion in oom doge.

2. Morphologic evidence of abatantelal numer: of prom ganglionte 3 mleron Llametex aypathetle libers hat been cenonetrated by al2ver otulning teehnique of cros sections of rentral roote from C-5 through $C-9$ of exparimental doge atimalated In (1).

3. The elgnteleance of our tinaing 11ea in the gact that any ourglon proceduren Involving aymatheotony of the upper extronlty by otellate gangllonectomy heve falled, therefore. the anatomle outflow denextbed above would acoount for many resldtul oxaphetie activities in numerous eurgloul conaitlons. 


\section{BrELIOCRAPIX}

1. Alexander, W.F., A. Kuntz, W.P. Henderaon, and $\mathbf{E}$, Ehrileh, (1949) Bympathotlo ganglion oello in ventral nerve roots. Thalr relation to sympathectomy. Sclence 109 : 484.

2. Bace, z.K. (1931) prénence, ans ihumeur aguause du lapen, dune substance sympathlcomimetique apres stimulation du sympathlque cervical. C.V. Beane. Soe. Blol. 107. 1504.

3. Baxeroft, H., M.MeK. Demman, and 0.6. Edholm. (1947) Reflex vasodilatation in human akeletal musele in remponee to heating the body, I. Phrelol. 106: 271 .

4. Barger, G. and $y . h$. Dalo. (1910) Dale-Chemleal otructure and

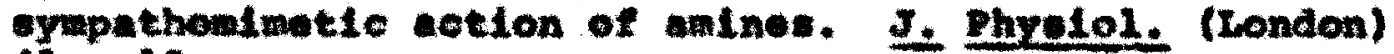
1: 19.

5. Bayl1s:, W.M. and J.R. Aradford. (1894) The Innervation of the vessele of the 11mbe. 3. Phyelol. 16: 10.

6. Boyd, J.D. and P.A.G. Honro. (1949) Partial retension of attonomic funetion aftar paravertebral aymathectomy. Lenoet 2: tos.

7. Boy,. J.D. (1957) Intermadiate aypathotie ganglion. Br1tish Med. Bul1. 13: 207.

8. Bridges. T.J. and A.D. Tahr. (1955) DLgital vasovotor responoes tollowing nerve root stimilition. Aroh. Manro. and Pschict. $74: 534$.

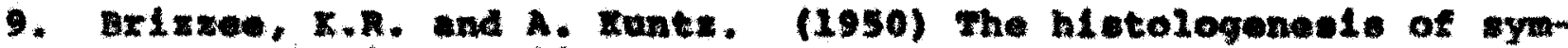
pathetle gang110n oells. J. Heuropath. and Exper. Neurel. 2: 164.

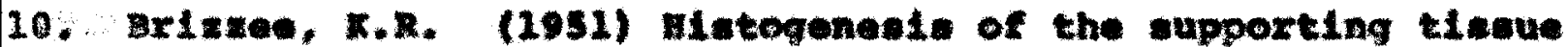
In the oplnal and aympenetie trunk ganglia in the chick. I. Conp. Neurod. 91 ; 129. 


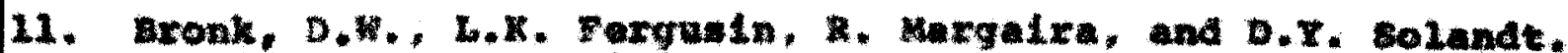
(1936) The activity of the cardiac apmpathete centere. An. I. Pbyelol. 117, 231.

12. Bulbring, $E$. and J.H. Burn. (1935) The grapathetle dilator tibere in the mucles of the oat and dog. J. Phrelol. 83. 483.

13. Burn, J.H. (1932) Tho cotion of tyramine and ophedrine. I. Phern. Exp1r. Thexap. 16. 75 .

14. Cox, J.W., W.C. Randal1, U.F. Alexander, F. . Franke, and A. B. Hertzman. (19S1) A method for the etudy of outaneoun

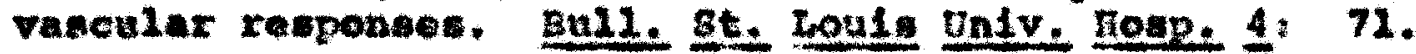

15. Dale, F.t. and W. Feldberg. (2934) Chemieal tranmisaton of secretory impulse: to weat glands of ent. J. Phyclol. (London) 82: 121 .

16. Dale, H.F., N. Felaberg, and N. Vogt. (1950) Feleace of acetyloholine in the entral nervone aystom. Hed. Bull. 6. 312.

17. Ehrlieh, E. and V.F. Alexander. (1951) snroloal Implleatlona of upper thoraclo independent sympathotio pathwaye. Arox. Euxrex 62:609.

18. Euler, 0.5. van. (1946) A meolfle symathomimetic ergone in adrenergle nerve fibers (sympthin) and ito relatione to acrenuline and nor-adrenuline. Acta Phyelol. Sand. 12: 73.

19. Feldberg. (1950) hole of adotlchollne in the central norvous aystes. British Med. Bul1. 6: 312 .

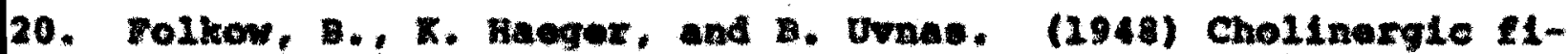
ber: in the sympathetio outelow to the muscle of the hind 1lmbs of the cat. Aota Phye1ol. Scand. 25, 4.

21. Folkow, B., J. Frost, R. Eaegex, and B. Wrat. (1949) The nympathetle vanomotor innervation of the in of the dog. Acta Phralel. Bonna. 16: 195.

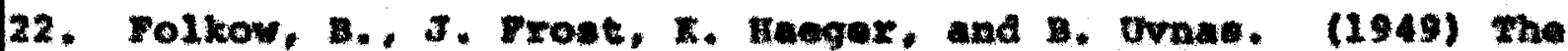
aympathetic vesomotor Innervation of the skin of the dog. Acta Phre101. Seand. 17, 195. 
23. Folkow, B. (1952) zmpula frequency in eymathetic vasomotor flbers correlated to the release and tranemltter. Acte Bhyelol. Soand. 25 is.

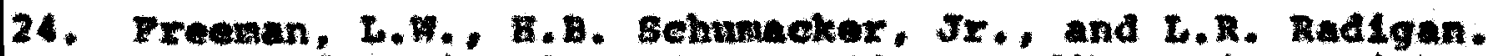

(1950) A functional ctudy of afterent tibere in pertpheral sympathetio nerves. Surgery 28; 274.

25. Gask11. W. (1986) On the mtrueture, dietribution and function of the nerves whoh innorvate the vieceral and vascular syaten. I. Phyelol. I: 1.

26. aase12, W.A. (2899) on the relation between the ctructure. tuiction. Alstribution and oriatn of the crantal nerves. J. Phystol. 20: 153 .

27. Gakk11, W.H. (1916) The Involuntary Bervoue Byeten. Inngman. axeen und comprny. Lonaton.

28. Geohegan. W.A, G.A. Wolfe, Ir., 0.J. Aldax, K, Haxe, and J. D. Hinsey. (1942) The oplnal orlgln of the pregangl1onle Libers to the $14 \mathrm{mb}$ in the cat and monkey. In. $\mathrm{J}_{\text {. }}$ Phyelol. 135: 324 .

29. Geohegan, W.A. and O.J. MLdor. (1942) Functional reorganization following preganglionectomy. Prog. Soo. Exp. Dlol. (Wew Tork) 50: 363 .

30. Grean, H.D., W. Havard, and L.F. Tenan, (1956) Autonomie control of blood low in hind paw of the alog. An. I. Pbxa101. 187: 469 .

31. Harmon, H. (1900) A study on the compostion of the human aysupathetic rami. I. Anet. Phyeiol." 34.

32. Hoffman, A.A. (1957) An malyalo of the oyapathetio trank and ravi in the cervieal and thoraclo raglons in wan. Anna1: of surrexy $145: 94$.

33. Jones, D.s. (2937) The oxigin of the aymathetic trunke in the chlek embryo. Anat. Rec. 70 , 45 .

34. Juba, A. (1930) A hietologieal deccription of the eonetitution of the vartou aymathetio rand of man. 2. Anat. I. Z. Anet. Enewgench. 22: 224 .

35. Kexslake, D.Mex. (1981) Abolition of narvous rellex vaeediletution by oympathoctomy of the hated 11mb. 3. Phyelod. $123: 7$. 


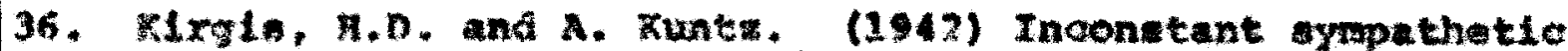
nawal pathway. Thait ralation to sympathetic denervation of the uppex extranity. Aroh. surg. 14: 95.

37. Funtx, A. (1909a) A contribution to the hlatogenasil of the aymothatio nexvous syster. Anat. Rec. 3: 158.

38. Tunte, A, and $0 . V$. Buteon. (1920) Experimental oberervations of the hiatogenes is of the vraptietic trunk in the chick. I. Cone. ieurol. 32, 335 .

39. Kuntz, A., F. Alexander, and C.I. Furtolo, (1938) Complate cympthetic denorvation of the upper extrenlty. Annals of Bargery 197 : 25 .

40. Kuntz, A, and J.A. DL11on. (1942) Preganglionte components of the elret thoracle nerve. Theif role in the eympathetis innervation of the upper axtendty. Arch. surg. (Chlaggo) 14: 772.

41. Kuntz, A. (1951) Azforent Inmervation of peripheral blood venel through yymathetio trunke. South., Med. I. 4 : 673.

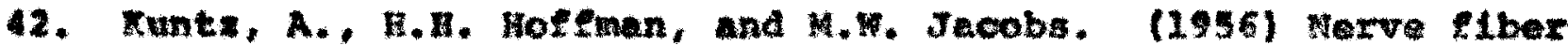
components of cowmunlcating raml and yypathetle roots In wan. Anat. Rec. 126: 29.

43. Lancley, J.K. (1678) on the phyalelory of callvaxy secretion. I. Pbyelol. 1: 96 .

44. Langley, J.N. and V.L. DLektusen. (1890) Plturl and nleotine. I. Phye101. 11: 265 .

45. Lungley, J.R. (1901) The difference of bohavior of central and peripheral pliometor nerve cells. I. Physiol. (toncon) 27: 224.

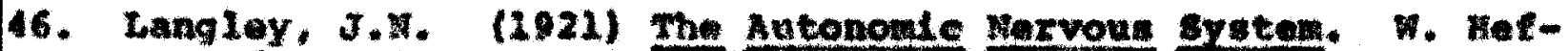
ter and sons. Cumbriage.

47. Lewandowsky, 4. (1898) Ueber elwe Wikung des Hebennlexenextracte ouf ane Auge. Zentel. Phyelol. 12, 599.

48. Low1s, T. and G.W. Plekering, (2931) Vasedilatation in the ilmo in responee to warming the body, wth evidence for - ymathetic vasodilator nerven in man. Ieart 16: 33 . 
49. Loov1, 0 . (1922) Debar humorala vebertragbarkeit der Hernnervenwirkung. I. Peluger' Areh. qes. PhyeloL. 183, 239.

50. Hurray. J.G. and J.W. Thompon. (1957) Collateral aprouting In romponse to injury of the $A . N .8$. , and lta conwequences. Brieivh Mea. Ball. 13; 213.

51. Pexxy, W.L.M. and J. Paleenlk. (1953) the role of acetylohoilne in ornaptic tranomiseion at parasympthatio ganglia. I. Pbrstol. (London) 219; 455 .

52. PLek, J. (1957) The ldentiflontion of aymathetio segmentis. Annals of Surgery 145: 3 .

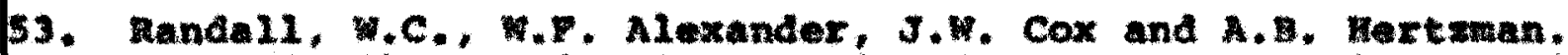
(1953) Functional anelysis of the vasomotor innervation of the doq" hind foot pad. Clre. Ree. 1: 16.

54. Rawson, R.O. (1961) Agphotoelectrio plethyanographlo study

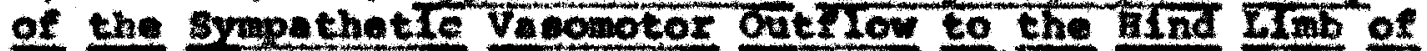

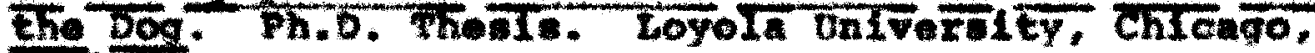
IIIñol:

55. Ray, E.B. and A.D. Conmole, (1948) Reslaual pathways after aympathectamy. I. Meurol. 3: 23.

56. Ray. B.S. and A.D. Conwole. (1949) bvaluation of total aympathectomy. Mnnals of Surgery 130, 652 .

57. Ray, B.8, (1953) sympetheotomy of the upper extremity-evaluetion of aurgloul mothods. I. Meurol. 10: 624.

58. Schaper. A. (1897) Dle fruhesten Differenzierungavorgange I:

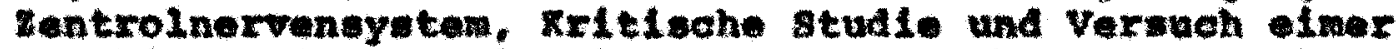
Ceschichte der Entwickelung nervoser substant. Arch. Enter.-Mech. 5: 01 .

59. Shoahan, D. and J. Plek. (1943) the rami communteantes in the rhesus monkey. I. Anat. (Tondon) 77,125 .

50. skoog, T. (1947) Ganglia in the communleating rasi of the cervleal syapathetle trunk. Imencet 2: 457.

51. strude1, G. (1952) Contribution experimentale au problende lorlgine des ganglions rochldens te symathetlque cher I'embryon de poulet. Compt. rend. Soc. Blol. $146,105$.

52. Uvnas, (1954) symathatio dilator outelow. Ehyelol. Rev. 34. 608 . 
58

63. Van Dublirk, $c$. (1941) Verveg in the vertebral canal. Thair rolation to the ympathetic innervation of the upper extratties. Arch. Surg. (Chicago) $43,427$.

64. Wrete, H. (1941) Dle Entwicklung and Topographie der 1ntermediaran vegetativen ganglien bel gewisain versuchetieren. zteche. 2elleargeh. u mikr. Arat. 49 : 503 . 


\section{APPROVAI. TEERT}

The thesis cubmitted by Cary $a$. Mlewan has been road and epproved by four nembere of the faeulty of the craduate school. The Ilnal coples have been examined by the directer of the thosts and the algnature Which appeare bulow verifies the tact that any neceseary changen have been ineorporated, and "ut the wheste is now glvon Inal approval weh reference to content. form, and wechenteal accuracy.

The thesi. is cherefore accepted in partial fulf112mant of the requiraments for the Deqree of Ha tax of gclenee.
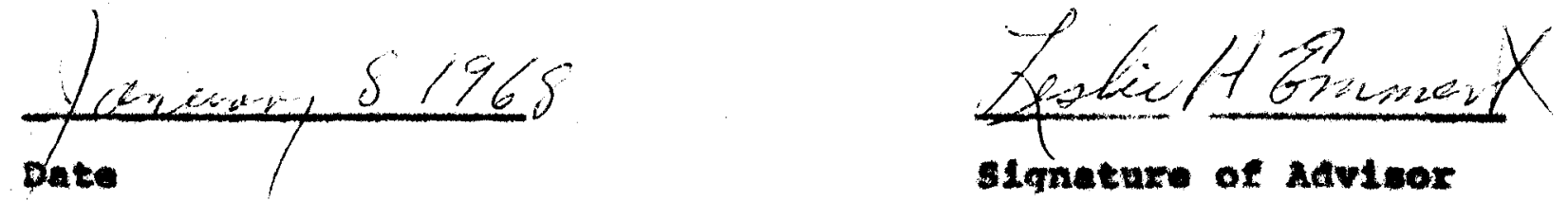


\section{Sympathetic Outflows from}

\section{Cervical Spinal Cord in the Dog}

Abstract. In some dogs there are preganglionic fibers leaving the cervical spinal cord through the ventral roots of the lower cervical nerves. When these fibers are stimulated electrically in the anesthetized dog with skeletal muscle paralysis (induced by decamethonium), the effects are vasoconstriction in the front footpad, cardiac acceleration and augmentation, and a rise in arterial blood pressure.

The sympathetic portion of the autonomic nervous system is often called "thoraco-lumbar" because preganglionic neurons have their cell bodies in the spinal cord from the first thoracic to the second or third lumbar levels. Axons of these preganglionic neurons leave the spinal cord through ventral roots of the thoracic and upper lumbar nerves and traverse the white communicating rami from spinal nerves to sympathetic trunks. If this anatomical description is correct, a person with a complete transection of the cervical spinal cord should have no sympathetic response to hypothalamic or other central nervous system activity. However, patients with cervical transections sometimes do have sweating responses which can be explained only by central nervous system influence over sympathetic outflow (1). Also, surgeons report that the sympathetic trunk can be severed above the first thoracic white communicating ramus and the inferior portion of the stellate ganglion removed without producing a Horner's syndrome, a condition in which there is a constricted pupil, dry and red face, and narrowed palpebral fissure due to loss of sympathetic innervation (2). This indicates that preganglionic axons reach the cervical sympathetic trunk superior to the first thoracic nerve.

The following experiments were performed on dogs to learn whether a sympathetic outflow from the cervical spinal cord could be demonstrated. Under $\alpha$-chloralose anesthesia, the cervical spinal cord and the cervical dorsal and ventral roots were exposed. Muscular blockade was induced by decamethonium. Intact ventral roots, as well as the distal end of severed ventral roots, were stimulated before and after section of dorsal roots. Sympathetic responses were interpreted from records made on a model 5 Grass polygraph from a Statham pressure transducer connected to the femoral artery to measure blood pressure, and a photoelectric plethysmograph (3) on the large central pad of the front foot to measure cutaneous volume pulses.

Results of stimulating the ventral roots of cervical nerves are shown in Fig. 1. The upper tracing of each pair is a record of femoral arterial pressure that shows relatively large oscillations synchronous with the positive pressure respirator. Note the rise in blood pressure (20 to $60 \mathrm{~mm}-\mathrm{Hg}$, systolic) and the marked increase in heart rate (60 to 100 beats per minute) during each stimulation period. There was a gradation in response, the least being elicited by stimulation at $\mathrm{C} 5$ (fifth cervical nerve) and the greatest at $\mathrm{C} 7$ and $\mathrm{C} 8$. Onset of the response was prompt (within 3 to 5 seconds) and recovery was complete approximately 30 to 45 seconds after cessation of stimulation. These data are interpreted to mean that preganglionic sympathetic fibers are present in the ventral roots of the lower cervical nerves. Sectioning of the spinal cord between $\mathrm{C} 8$ and $\mathrm{T} 1$ (first thoracic nerve) did not prevent the response.

The lower tracing of each pair of records shows the changes in pulse amplitude in the footpad. Decrease in amplitude is due to vasoconstriction and decreased volume of blood flow through the footpad during each pulse. These data are also interpreted to in-
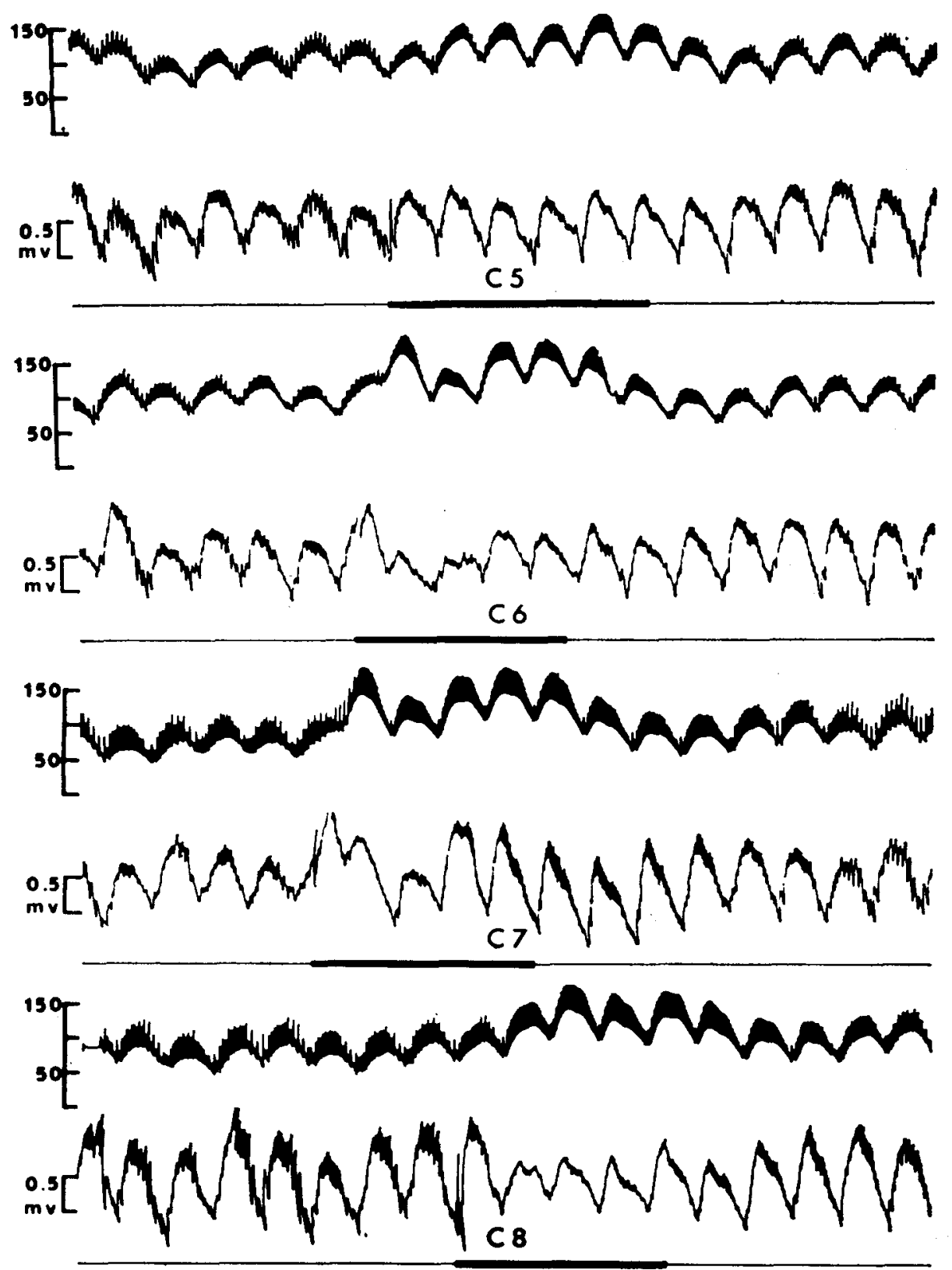

Fig. 1. Results of the stimulation of ventral roots of cervical nerves $\mathrm{C} 5, \mathrm{C} 6, \mathrm{C} 7$, and C8. Upper tracing, blood pressure; middle tracing, cutaneous volume pulse; and bottom line, time of stimulation. Paper speed, $2 \frac{1}{2} \mathrm{~mm} / \mathrm{sec}$. 